\title{
الحماية القانونية لذوي الاحتياجات الخاصة هن جرائم الاتجار بالبشر في الأردن
}

\author{
shel
}

د / محمد موسى عواد السويلميين

أستاذ مشارك القانون- ككليت الأعمال

قسم التخطيط وإدارة المشاريح_ الأردن 
إن الكنية المعاصرة للعبودية هي ظاهرة الاتجار بالبشر، لمـا فيها من استغلال

للعوز و العجز الجسدي والنفسى للأشخاص ذوي الإحتياجات الخاصة ، ولم تكن ظاهرة ورثت من المجتمعات البدائية وزالت وانتهت بمرور الزمن وتطور المجتمعات الحديثة بل نجد أنها لم توجه بحق الدولة أو المجتمع فقط، بل صـارت توجـه إلى ذات الإسسان وتنتقص من حريته وأدميته التي فضل فيها الخـالق ـعز وجلـ الإنسان على سـائر

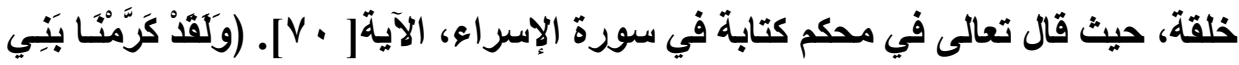

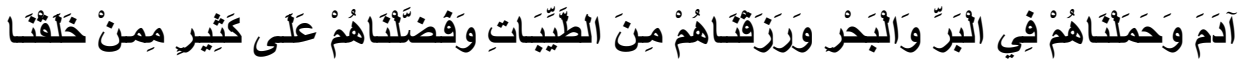

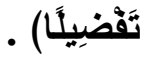

ومع تطور المجتمعات البشرية اتسعت صور وألوان هذه الظاهرة الخطرة، حيث لم تعد قاصرة على عملية كون الإنسان تابعا لأخر ومنقادا له مع سلب حريته والحط من كرامته الإنسانية بل تعدته إلى بيع أعضاءه كقطع غيار بثرية أو استغلاله لغرض نقل وتهريب أمور ممنوعة قانونا، ويكون ذلك عبر الوطنية وغيرهـا من الأعمـال المخالفـة للثرع والقانون، وقد أضحت هذه الآفة مشكلة تؤرق الضمير الإنساني للبشرية وتقلق المجتمع الدولي برمته ومع تطور صور السلوك المختلفة الخاصـة بهذه الظـاهرة فقد باتت أشكالها المتعددة تمثل انتهاكا فاضحا لحقوق الإنسان وحرياته الأساسية والتي سبق أن نص عليها في مختلف الصكوك الدولية ذات العلاقة، ومن أهمها: الإعلان العالمي لحقوق الإنسان والعهد الدولي للحقوق الاجتماعية والاقتصادية"('). وعلية نجد أن العديا من التشريعات الوضعية قد تصدت لهذه الآفة إلا أن أهم ما يلاحظ على ذلك أن

(1) Karin, Hess and Orthmann, Christine, Criminal Investigation, ninth edition, Canada, 2009. P.9. 
تلك التشريعات الوضعية جاعت معالجتها متأخرة تارة وغير شاملة لجميع أحوالها تارة أخرى ولعل مرد ذلك قد يكون جملة أسباب (")، وكما سنرى ذلك لاحقا بين ثنايـا هذا البحث.

إن جريمة الاتجار بالبشر من أبشع الجرائم ضد الإنسانية، جعلت من الإنسان

سلعة تدر الأرباح على المتاجرين، وهي ثنالث جريمـة على مستوى العالم بعد تجـارة

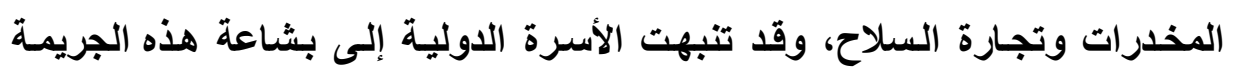

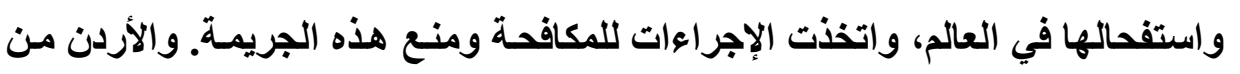

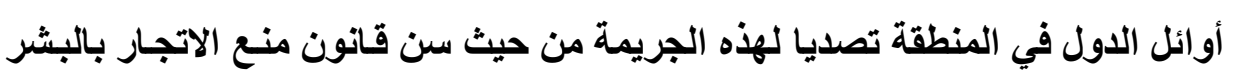

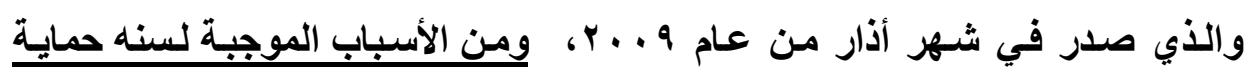
الأشخاص ذوي الإحتياجات الخاصة من الإتجار بهـم من خلال استخلإل للعوز والعجز الجسدي والنفسى لايهموهو ثالث قانون في المنطقة العربية بعد القانونين البحريني

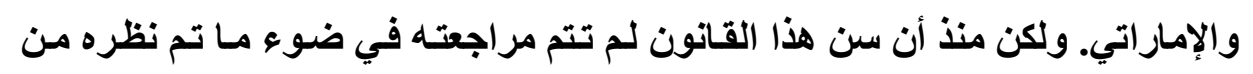

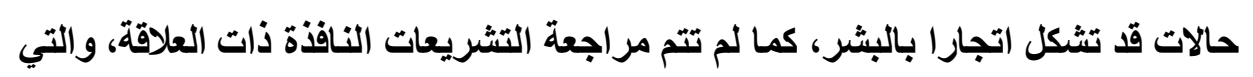
قد تشكل بيئة خصبة للاتجار بالبشر (ن). إن مكافحة الاتجار بالبشر تشمل الوقاية والحماية للضحايا والملاحقة الجزائية للجناة، ولذا قد يكون في بعض نصوص التشريعات النافذة مـا يعيق التعرف على التى الضحايا وملاحقة المتاجرين وضعف الحماية.

(1) ناصر راجح الثهراني: الإطار التشريعي لمكافحة الاتجار بالبشر في المملكة العربية السعودية،

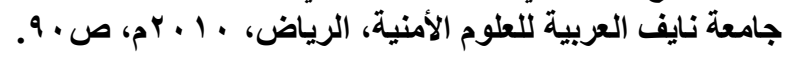

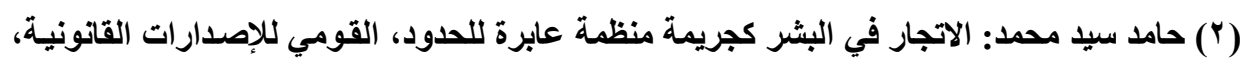

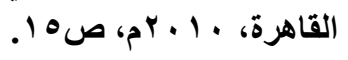


وفي عام ( • ( • ) أطلقت الإستراتيجية الوطنية لمكافحة الاتجار بالبشر، على

أن تتفذ بنودها خلال سنتين، وقد كان من ضمن بنود هذه الإستراتيجية مراجعة

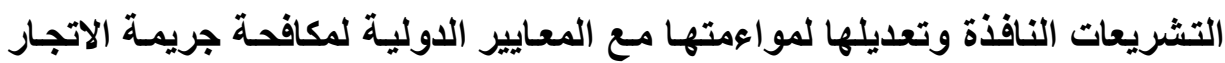
بالبشر، إلا أنه ورغم انتهاء مدة هذه الإستراتيجية، لم تتم مراجعة التشريعات. ومن منطلق شر اكة مؤسسات المجتمع المدني ودورهـا في تعزيز حقوق الإنسان، وحمايـة ضحايا الاتجار بالبشر، قام مركز تمكين للاعم والمساندة من خلال فريق من الباحثين القانونيين ذوي الخبرة بمراجعة وتحليل التشريعات النافذة ومدى مواعمتها مع المعايير

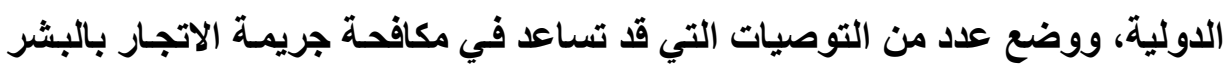
وحماية العمال المهاجرين(')وقد أدى تنازع القوانين والثغرات في بعضها إلى صعوبة التعرف على ضحايا الاتجار بالبشر ومن وقع عليه انتهاكـات جسيمة لحقوقه العماليـة من العمال المهاجرين وغيرهم من الفئات المستضعفة، ممـا أدى إلى ضعف في في حمايـة حقوق هذه الفئة، وإفلات الجنـاة من العقـاب، كمـا أدت الثغرات في التشريعات إلى من صعوبة تنفيذها، وبالتالي صعوبة الوصول للعدالة، مما أدى إلى التعامل مع العديد من

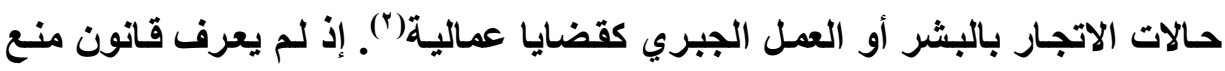
الاتجار بالبشر الجريمة بشكل واضـح، كما لا ينص بوضوح على حقوق الضحايا ولا يفصلها ولا ينص على كيفية الحماية، كما تخلو التشريعات عامة من أي نص على منح

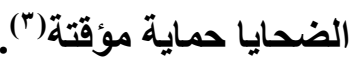

( (1) وسيم حسام الاين الأحمد: الحماية القانونية لحقوق المعاقين ذوي الاحتياجات الخاصة، منشورات

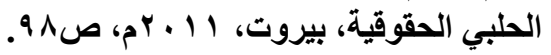

(2) Osterburg, James and Ward, Richard, Criminal Investigation: A method for Reconstructing the Past, Sixth edition, USA, 2010. P31.

(ए) فها بن محمد الحمد: حماية الطقل في نظام مكافحة جرائم الاتجار بالأشخاص، رسـالة ماجستير،

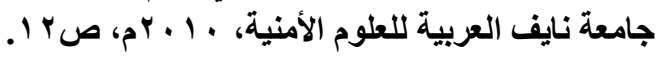


وللوقـوف على حيثيـات موضـوع الدراسـة يتعسين التعـرض لمحساور التعريـف بموضوعة والتي تشمل بيان أهميته ومشكلته وأهدافه ومنهجيته و الدراسـات السابقة فيه ومحتوى خطة دراسته وفقا للآتي :أولا :-أهميمية هوضوضع الدراسة:-

تتبع أهمية الاراسة من كونها تناقش موضوعا ذي أهمية خاصة على الصعيا الوطني وعلى الصعيد الدولي في آن واحد، فالأردن ملتزم بمقتضى مواثيق دولية بمنع مونع الإتجار بالبشر حمايـة للأشـخاص ذوي الإحتياجـات الخاصـة وكفالة حقوق العـــال المهاجرين وحظر العمل القسري، وأن أي إخلال بهذه الالتزامات أو تقصير في تنفيذها من خلال التشريعات الوطنية قد ينعكس سلبا على صورة الأردن أمام الجهات والهيئات

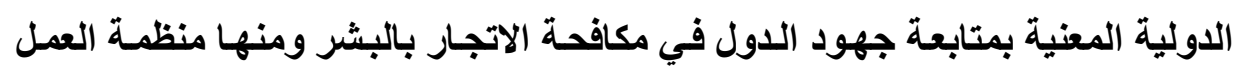
الدولية، مجلس حقوق الإنسان، تقارير اللجان الاتفاقية. ثانيا :-هشكلة هوضوع الدراسةة: رغم قيام الأردن بتفيذ التزاماته الدولية بشأن تجريم الاتجار بالبشر وإصدار التشريعات اللازمـة، إلا أن الممارسـات العملية والنصوص التشريعية في كثير من الأحيان لا تزال بعيدة عن تحقيق متطلبات المعايير الدولية، مما يجعل موقف الأردن من

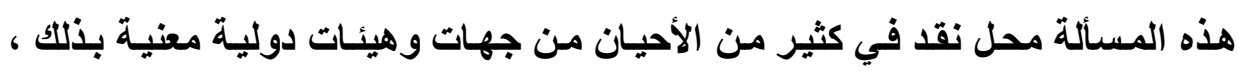

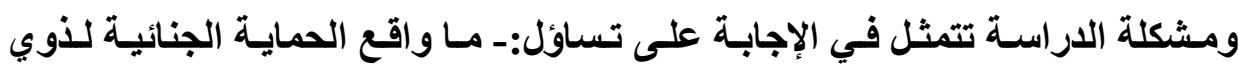
الاحتياجات الخاصة من جرائم الاتجار بالبشر في الأردن؟ ، وما ينبثق عن هذا التساؤل من الفرضيات الفرعية الآتية: ا - ما مفهوم ذوي الاحتياجات الخاصة؟ r - ما مفهوم وطبيعة وأسباب جرائم الاتجار بالبشر؟ 
r- ما حقوق ذوي الاحتياجات الخاصة في المواثيق الدولية والأردنية؟ ع - ما صور الحماية الجنائية لذوي الاحتياجات الخاصة من جرائم الاتجار بالبشر؟

ثالثا :- أهداف هوضوع الدراسة: -

يهرف موضوع الدراسة إلى:-

1ـ التعرف على مفهوم ذوي الاحتياجات الخاصة.

r - توضيح مفهوم وطبيعة وأسباب جرائم الاتجار بالبشر.

rــ التعرف على حقوق ذوي الاحتياجات الخاصة في المواثيق الدولية والأردنية. ــ التعـرف على صـور الحمايـة الجنائيـة لذذوي الاحتياجـات الخاصـة مـن جرائم الاتجار بالبشر.

هـ بيان مدى وفاء الأردن بالتزاماتـه الدولية بخصوص تجريم ومكافحة الاتجـار بالبشر.

7- تحديد مدى توافق التشريعات الأردنية مع المعايير الدولية بخصوص مكافحة

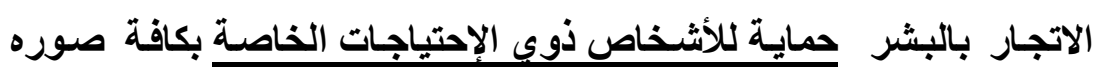
وأشكاله، وذلك فيما يتعلق بالوقاية والحماية والملاحقة. Vـ تحديد حقوق ضحية الاتجار بالبشر في التشريعات الأردنيـة مقارنـة بالمعايير

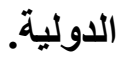
1ــ الخروج بتوصيات لتظوير التشريعات النافذة من أجل توفير الحمايـة اللازمـة لضحايا الاتجار بالبشر وتجريم الأفعال التي من شأنها أن تقود لجريمة الاتجار بالبشر. 


\section{رابعا :- هنهج هوضوع الدراسة :-}

اتبع الباحث المنهج الوصفي التأصيلي التحليلي المـوازن بتحليل المضمون، وذلك عبر دراسة وتحليل النصوص القانونية ذات الصلة بموضوع الدراسـة ومقارنتها بالمعايير الدولية، والذي تم من خلال جمع وتحليل التثريعات الوطنية النافذة.

خاهسا :- الدراسات السابقة في الموضوع:-

تـشير مراجعـة البحـوث والاراســات التــي أجريــت فــي مجـال الطـلاب ذوي الاحتياجات الخاصة، أن هذا المجال نـال في الآونـة الأخيرة اهتمـام عدد غير قليل من فن الباحثين، حيث تناولت بعض الدراسات العوامل المؤثرة في عملية الدمج، وحجم تلك التأثثرات، بينما تناولت دراسـات أخرى الاتجاهـات نحو دمـج الأطفال المعاقين وكيفية تعديلها، كما لم تغفل تلكت الدراسات دور التعديلات المتوافرة في بيئة الدمج والخدمات المساندة والتي بدونها قد يتعثر الأطفال المدمجون بشكل كبير. إلا أن مسح البحوث والدراسات التي تناولت تأثيرات اللدمج وفوائده على ذوي الاحتياجات الخاصة والمجتمع، يشير إلى افتقار المكتبة العربية بهذا الخصوص، وهناك مجموعة من الدراسات التي تناولت علاقة الدمج ببعض المتغيرات، وهي في مجملها ذات صلة غير مباشرة بموضوع الاراسة الحالية، إلا أنها قد تساعد في إلقاء الضوء على فوائد دمج ذوي الاحتياجات الخاصة أكاديميا واجتماعيا.

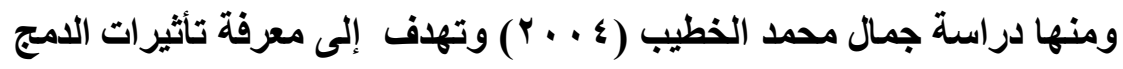
على القبول الاجتمـاعي للأطفال ذوي الحاجـات الخاصـة من قبل أقرانهم العـاديين.

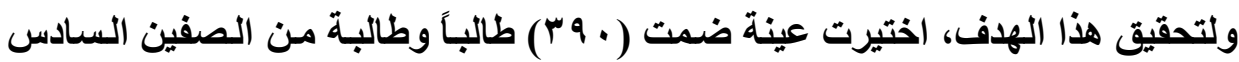
والسابع في أربع مدارس، اثنتان منها تنفذان الامج والاثنتان الأخريان لا تنفذان الدمج. أشارت نتائج الدراسة إلى أن مستوى القبول الاجتماعي للأطفال ذوي الحاجات الخاصة 
من قبل أقرانهم العاديين كان مرتفعاً نسبياً، ولكنه كان أكثر ارتفاعاً وبثكل دال إحصائياً

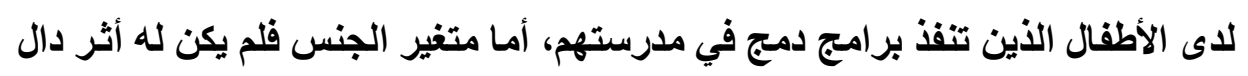
حيث لا توجد فروق جوهرية بين استجابات الذكور والإناث.

أما دراسة نعمه عبد الفتاح (9999 (19) و التي كانت تهاف إلى قياس عائد التدخل

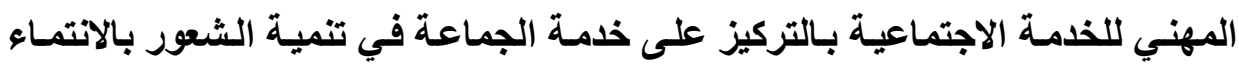

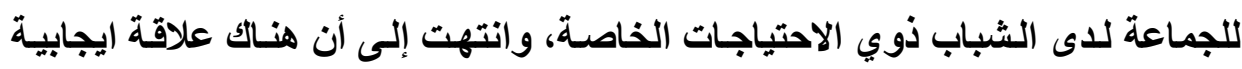

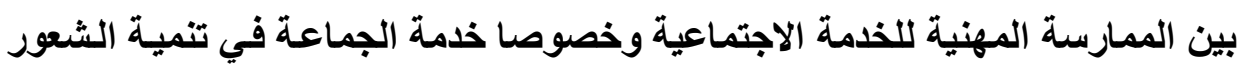
بالانتماء لاى ذوي الاحتياجات الخاصة.

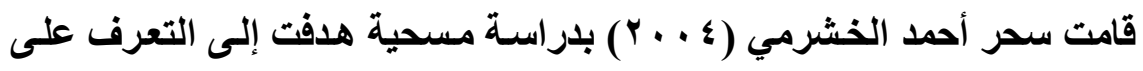

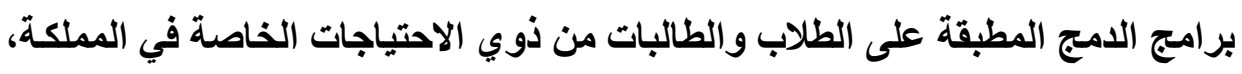

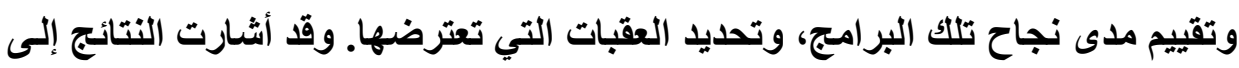

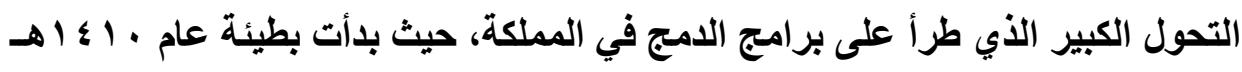

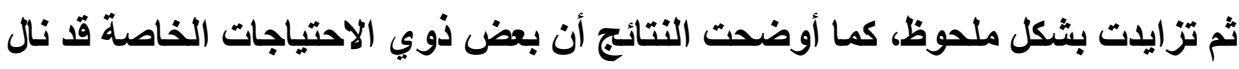

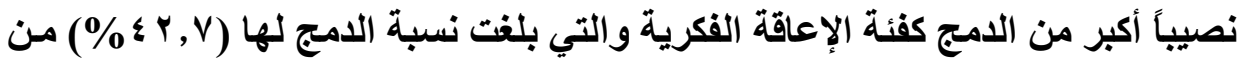

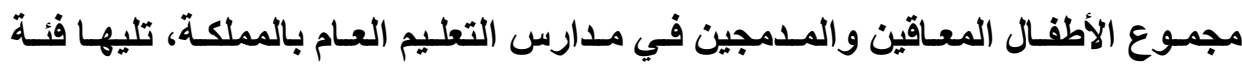

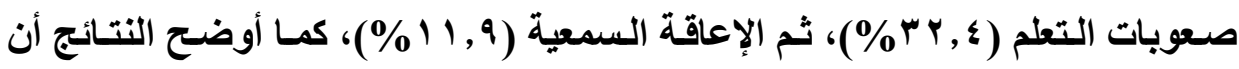

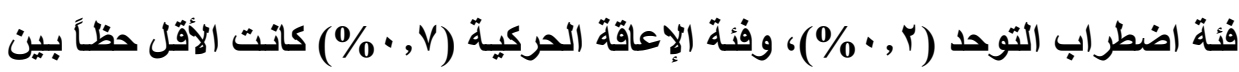

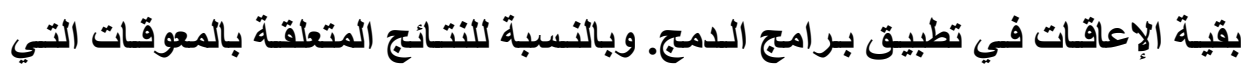

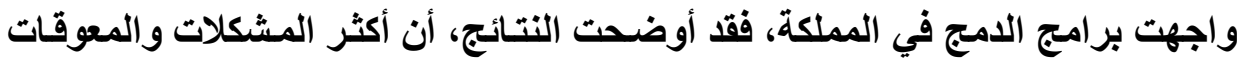
التي تواجه الادج تعود إلى الاتجاهات السلبية نحو الأفراد المعاقين، يليها نقص الخبرة

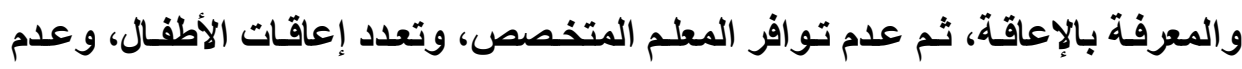

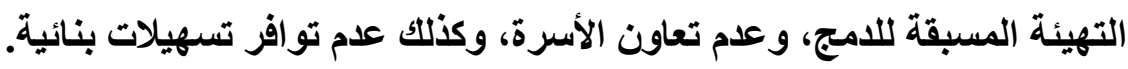


أما دراسة محمد رفعت قاسم، وبلر الدين كمال (^ . . . ) والتي كاتت تهذف إلى التعرف على علاقة تعزيز الانتماء للجماعة بزيادة قرة ذوي الاحتياجـات الخاصـة على ولى تحدي الإعاقة، وقد توصلت الدراسة إلى أهمية برامج التدخل المبكر في تنمية الشعور بالانتمـاء للجماعـة لـدى ذوي الاحتياجـات الخاصـة، وزيـادة معدل انتشـار العلاقـات الاجتماعية بعد التدخل المهني، وزيـادة القدرة على تأكيد الذات، وزيـادة القدرة على

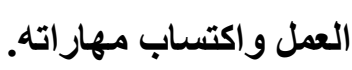

\section{سادسا :- هحتوي خطة هوضوع الدراسة :-}

تبيانـا لمحساور التعريـف بموضسوع الدراسـة سـنعالجه مـن خـلال خطـة دراسـية محتواهـا ثلاثـة مباحـث وخاتمـة فهي المبحث الأول نتـــاول مفهـوم ذوي الإحتياجـات

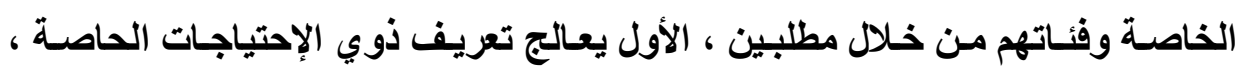
والثاني يعالج فئات ذوي الإحتياجـات الخاصـة وأسبابها، وفي المبحث الثاني نتــاول مفهوم جرم الإتجار بالبشر من خلال مطلبين، الأول يعالج تعريف جرم الإتجار بالبشر، الإبهاب والثاني يعالج أسباب ظاهرة الإتجار بالبشر، بينما المبحث الثالث يتـاول واقع الحمايـة القانونيـة لـذوي الإحتياجـات الخاصـة مـن جـرم الإتجـار بالبشر فـي الأردن مـن خـلال مطلبين ، الأول يعالج مبدأ الإلتزام بتجريم ظاه رة الإتجار بالبشر في الأردن ، والثاني يعالج نطاق الحماية القانونية لذوي الإحتياجـات الخاصة من جرم الإتجـار بالبشر في الأردن، وفي الخاتمـة نتــاول النتـائج والتوصيات، وعلى ضـوء هذا المحتوى تكون

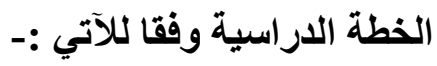
مقدمة عامة

التعريف بموضوع البدراسة

أولا :-أهمية موضوع الدراسة 


$$
\begin{aligned}
& \text { ثانيا :-مشكلة موضوع الدراسة } \\
& \text { ثالثا :- أهداف موضوع الدراسة } \\
& \text { رابعا :- منهج موضوع الدراسة } \\
& \text { خامسا :- الاراسات السابقة في الموضوع } \\
& \text { سادسا :- محتوي خطة موضوع الدراسة }
\end{aligned}
$$

المبحث الأول :- مفهوم ذوي الإحتياجات الخاصة وفئاتهم

المطلب الأول:- تعريف ذوي الإحتياجات الخاصة

المطلب الثاني :- فئات ذوي الإحتياجات الخاصة وأسبابها

$$
\text { المبحث الثاني :- مفهوم جرم الإتجار بالبشر }
$$$$
\text { المطلب الأول :- تعريف جرم الإتجار بالبشر }
$$

المطلب الثاني :- أسباب ظاهرة الإتجار بالبشر

المبحث الثالث :- واقع الحمايـة القانونية لذوي الإحتياجـات الخاصـة من جرم الإتجـار

$$
\text { بالبشر في الأردن }
$$

المطلب الأول :- مبدأ الإلتزام بتجريم ظاهرة الإتجار بالبشر في الأردن

المطلب الثاني :- نطاق الحمايـة القانونيـة لذوي الإحتياجـات الخاصـة من جرم الإتجـار

$$
\text { بالبشر في الأردن }
$$




\section{المبحث الأول}

\section{مفهمم ذوي الاحتياجات الخاصة وفنئاتهم (1)}

لقد أدي الالتفـات إلـي الأهميـة البالغة لمفهوم رأس المـال البشري ودوره في نهضة المجتمع وتقدمه إلي أيلا أولوية متقدمة للتنمية البشرية في مجالات مثل: رعاية الفقر اء المهمشين وذوي الاحتياجات الخاصة وغير هم كي نستفيد بما لايهم من طاقات، وتركيزنـا هنـا علـي ذوي الاحتياجـات الخاصـة فلكي نمكن لهم داخل المجتمع لابد من تـأهيلهم وتعليمهم وإدمساجهم في مجتمعهم كقوي منتجـة وفاعلـة. فذوي الاحتياجـات الخاصة مصطلح يثمل كل الفئات التي تحتاج إلي نوع خـاص من الرعايـة سواء كاتـ جسمية أو نفسية أو اجتماعية أو تربوية وتختلف قضايا ومشكلات وطرق رعايـة كل فئة من هذه الفئـات لاختلاف احتياجـاتهم(؟)سنتناول هذا المبحث من خـلال المطلبين الآتيين :-

\section{المطلب الأول:- تعريف ذوي الإحتياجات الخاصة}

المطلب الثاني :- فئات ذوي الإحتياجات الخاصة وأسبابها

المطلب الأول:- تعريف ذوي الإحتياجات الخاصة :-

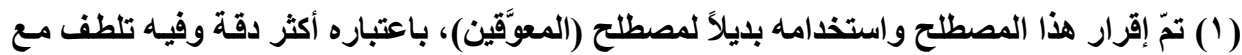

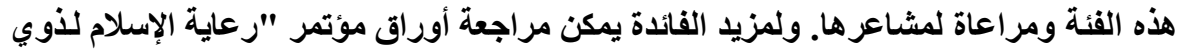

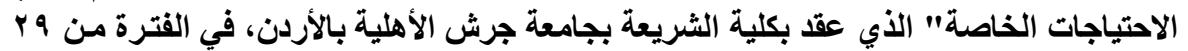

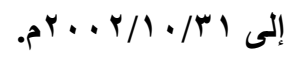

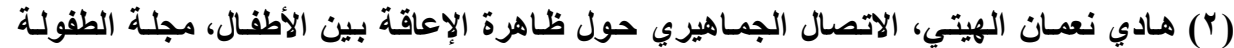

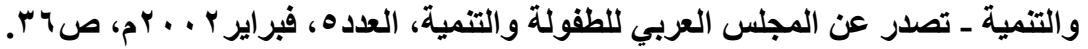


إن من أهم متطلبـات تمكين ذوي الاحتياجـات الخاصـة هـي تـوفير كافـة أشكال

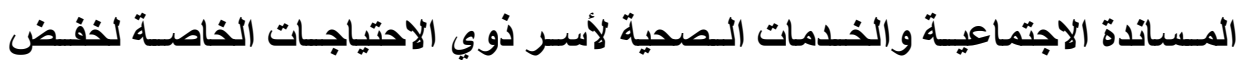
مستويات الـضغوط النفسية الواقعـة علـي هـذه الأسـر("). وتششير ( Fahmeeda

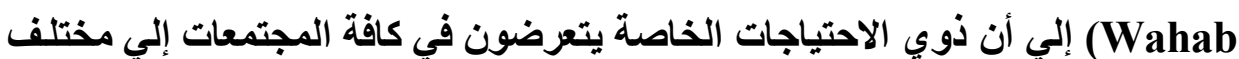
صور التمييز السلبي وخاصة الاستبعاد من كافة فعاليات وخبرات الحياة الاجتماعية،

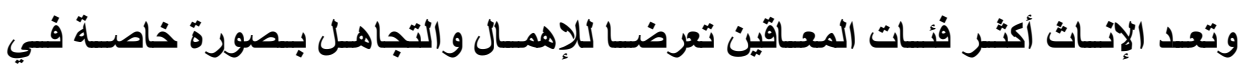
المجتمعـات النامية، وفي المنــق الريفيـة وترصد (Fahmeeda) الكثير من صور التحيز السلبي ضد النساء المعاقات في الدول النامية في أسيا منها: قلة الدعم المـادي المخصص للإنفاق في مجال تعليم الأطفال والمراهقين من الإناث المعاقـات، إضـافة إلي عدم تأهيلهم بالصورة الكافية لدمجهم في المجتمع، وبنـاء علية تترك المرأة المعاقة علي هامش المجتمع تعاني من العزلـة الاجتماعيـة والنفسية وتتعرض للنبذ والإهمال الاجتمـاعي وينظر إليهـا بوصـفها عبـئ علـي المجتمـع ويـدلل علـي ذلك الكثير مـن الإحصائيات التي تظهر بوضوح الظلم الاجتماعي البين الواقع علي النساء المعاقات في العديد من الدول الآسيوية"(؟). وترجع ذلك إلي القصور في التشريعات القانونية المتعلقة بتعليم ورعايـة هذه الفئة، وهي تعد من ضمن أهم الأسباب التي ترتبط بهذا الظلم الاجتمـاعي، وتؤكد بنـاء علي ذلك علي ضرورة إدخال تشريعات قانونية تدعم حق هذه الفئة وتمكن لهم فرص

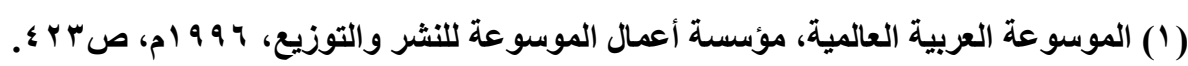

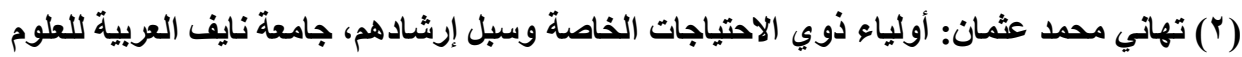

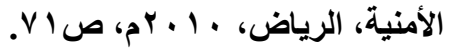


متكافئة(') وأحيانا ما تتسم النظرة إلي وصول طفل معوق في الأسرة بـالخوف والقلق والشعور بحلول كارثة...، وقد تعدد الأسرة إلي عزل الطقل المعوق عن البيئة المحيطة (الخوف علية من عدم التكيف، التجنب لما يرتبط بتدريبه وتعليمه وخدمته، الصعويات والمشاكل المترتبة علي ذلك الوقت والجها) ـوقد يكون للأسرة بعض العذر في ذلكـ غير أن ما يجب الإشارة إليه هو أن آثار الإعاقة السلبية تؤثر تأثيرا عميقا في نفسية

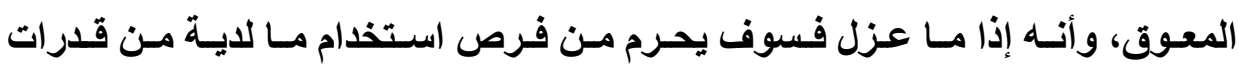
واستعدادات ومهارات، وتستطيع الأسرة إذا مـا تقبلت الطفل المعوق بشكل طبيعي أن تساعده علي تقدير نفسه بشكل واقعي والتخطيط لحياتـه أو تقييم قدراتـه واستعداداته بصورة صحيحة دون زيادة أو نقصان (") ولقد شهر العقد الحالي تطوراً هائلاً في مجال الاهتمـام بالإعاقة. ونشطت الدول المختلفة في تطوير برامجها في مجال الإعاقة، لأن الاستجابة الفعالة لمشكلة الإعاقة يجب أن تتصف بالشمولية، بحيث لا تهتم ببعض الجوانب المتعلقة بهذه المشكلة وتغفل جوانب أخرى، وبشكل يكون فيه لبرامج الوقاية من الإعاقة أهمية متميزة؛ نظراً لأنها تمثل إجراءً مبكراً يقلل إلى حد كبير من وقوع الإعاقة ويختصر الكثير من الجهود المعنوية والمادية اللازمة لبرامج الرعاية والتأهيل. وتعرف التربية الخاصـة بأنها نمط من الخدمات والبرامج التربويـة، تتضمن تعـيلات خاصـة سـواءً في المنـاهج أو الوسـائل أو طرق التعليم، اسـتجابة للحاجـات الخاصة لمجموع الطلاب الذين لا يستطيعون مسايرة متطلبات برامج التربية العادية (1) إسماعيل محمد حنفي: دور الدولة في رعاية ذوي الاحتياجات الخاصة في الإسلام، مجلة الثريعة الإسية

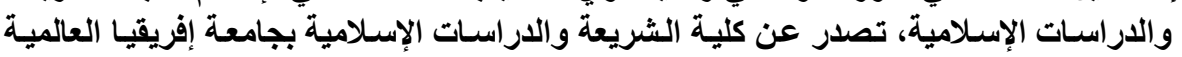

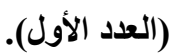

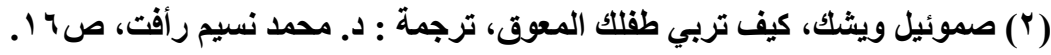


كما تعرف التربية الخاصة على أنها: "مجموعة البرامج التربويـة المتخصصة والتي تقام لفئات من الأفراد غير العاديين وذلك من أجل مساعدتهم على تنمية قدراتهم إلى

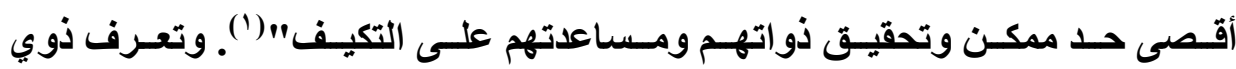
الاحتياجات الخاصة: بأنهم "أفراد يعانون نتيجة عوامل وراثية أو بيئية مكتسبة من

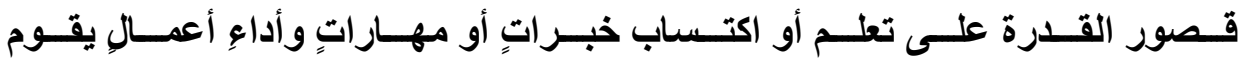
بهـا الفرد العـادي السليم المماثل لهم فـي العمـر والخلفيـة الثقافيـة أو الاقتصادية أو

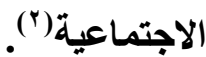

ولهـذا تصبح لهم بالإضـافة إلى احتياجـات الفرد العـادي، احتياجـات تعليميـة، ونفسية، وحياتية، ومهنية، واقتصادية، وصحية خاصة، يلتزم المجتمع بتوفير هـا لهم؛ بحسبانهم مواطنين وبشراً ـ قبل أن يكونوا معوّقين ـ كغير هم من أفراد المجتمع. وتعرف الإعاقة على أنها: "حالة من القصور أو الخلل في القدرات الجسدية أو الذهنية ترجع إلى عوامل وراثية أو بيئية تعوق الفرد عن تعلُم بعض الأنشطة التي يقوم

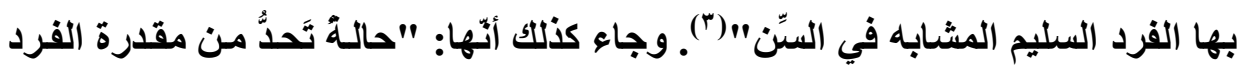
على القيام بوظيفةٍ واحدةٍ أو أكثر من الوظائف التي تعدُّ من العناصر الأساسيـة للحيـاة

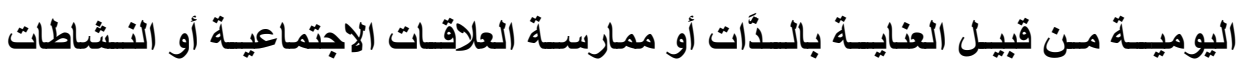

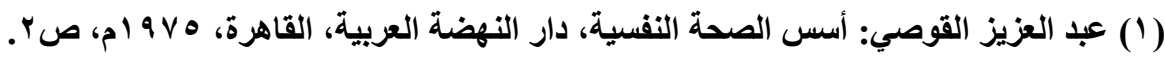

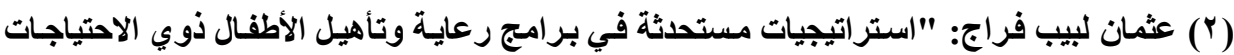

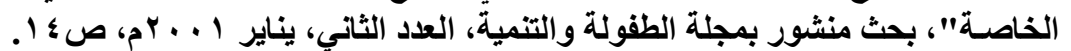

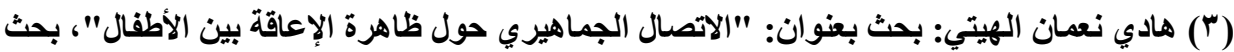

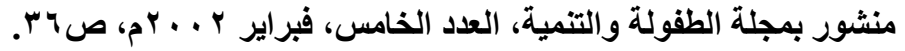




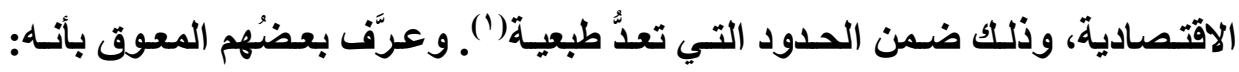

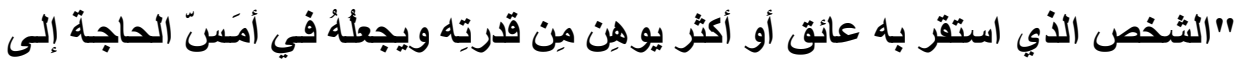

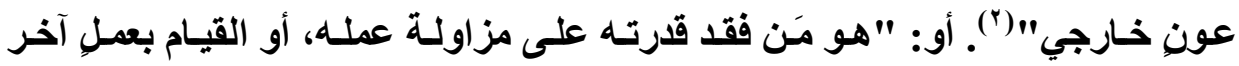
نتيجة لقصور بلدي أو جسمي أو عقلي، سواءُ كان هذا القصور بسبب إصـابته في حادثٍ أم مرض أم عجز ولادي" "(").

\section{الإطلب الثاني}

\section{فئات ذوي الإحتياجات الخاصة وأسبابها}

يقصد بالأشـخاص ذوي الاحتياجـات الخاصـة بـأنهم هـم كل فرد يحتـاج طوال

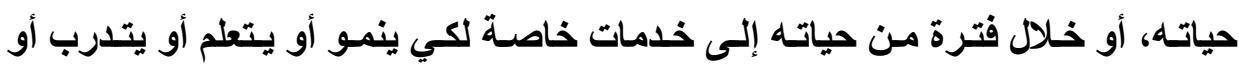
يتوافق مع متطلبات حياته اليومية والأسرية أو الوظيفية أو المهنية، ويمكنه بـلكل إلى يشارك في عمليات التنمية والاجتماعية والاقتصادية، بقدر مـا يستطيع وبأقصى طاقته كمواطن، ومـن ثم هؤلاء الأطفـال هم ذوو الحاجـات الخاصـة. وينتمـي الفرد مـن ذوي الحاجات الخاصة إلى فئة أو أكثر من الفئات التالية(؛) :

(1) هـادي نعمان الهيتي: بحث بعنوان: "الاتصال الجمـاهيري حول ظـاهرة الإعاقة بين الأطفـال"، مرجع سابق، نفس الصفحة. (Y) محمد عبد المنعم نـور: الخدمـة الاجتماعيـة الطبيـة والتأهيل، دار المعرفة، القـاهرة، ه19 امج،

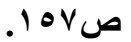

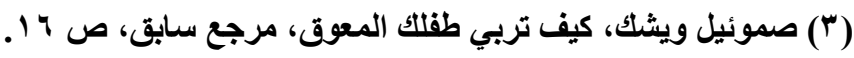

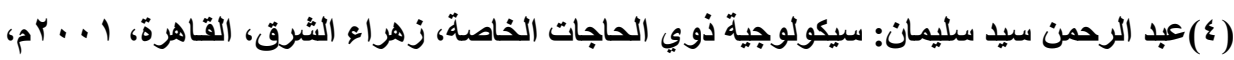


1 الموهبة والتفوق (Talent and Giftedness)

r ـ الإعاقة العقلية (Mental Handicap)

r- الإعاقة السمعية (Hearing Impairment)

ع- الإعاقة البصرية (Visual Impairment)

•ـ الإعاقة الحركية (Physical Impairment)

ד- الإعاقة الانفعالية (Emotional Impairment)

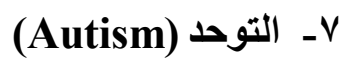

^ـ صعوبات التعلم (Learning Disabilities)

9ـ اضطر ابات النطق أو اللغة (Speech and Language Disorders)

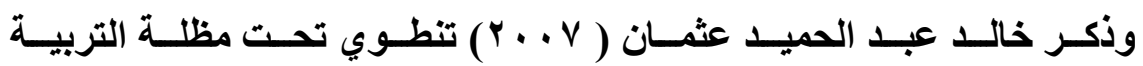

الخاصـة الفئـات الآتيـة: الإعاقة الفكريـة، الإعاقة البصرية، الإعاقة السمعية، الإعاقة

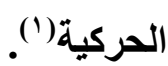

الفرع الأول:-أهداف التزبية الفاصة:

تهدف التربية الخاصة إلى ما يلي(؟):

(1) خالد عبد الحميد عثمان: مظاهر الصحة النفسية لذوي الاحتياجات الخاصة، V. V. V م،

http://www.jtc.edu.sa/articles.aspx?id=1297\&selected id1303\&page

$\underline{\text { size }=5 \text { \&links=true \&gate } \mathrm{id}=1217}$

(r) تهاني محمد عثمان منيب: أولياء ذوي الاحتياجات الخاصة وسبل إرشادهم، جامعة نايف العربية

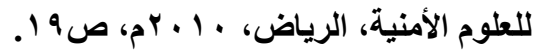


1- التعرف إلى الأطفـال غير العـاديين وذلك من خلال أدوات القيـاس والتشخيص المناسبة لكل فئة من فئات التربية الخاصة. r- إعادة البرامج التعليمية لكل فئة من فئات التربية الخاصة. r- إعادة طرائق التدريس لكل فئة من فئات التربية الخاصـة، وذلك لتنفيذ وتحقيق أهداف البرامج التربوية على أساس الخطة التربوية الفردية. ع - إعداد الوسائل التعليمية والتكنولوجية الخاصة بكل فئة من فئات التربية الخاصة هـ إعداد برامج الوقاية من الإعاقة، بشكل عام، والعمل على تقليل حدوث الإعاقة

$$
\text { عن طريق البرامج الوقائية. }
$$

צ- مراعـاة الفروق الفرديـة بين الطلاب، وذلك بحسن توجيهم ومساعدتهم على النمو وفق قرراتهم واستعداتهم وميولهم. V- تهيئة وسائل البحث العلمي للاستفادة من قدرات الموهوبين وتوجيهها وإتاحة الفرصة أمامهم في مجال نبوغهم. ^ــ تأكيــ كرامـة الفـرد وتـوفير الفـرص المناسـبة لتنميـة قدراتـه حتـى يستنطيع المساهمة في نهضة الأمة.

الفرع الثاني :-أنواع الإعاقات في همال التربية الخاصة وتصنيفها :تصنيف الإعاقة هو تقسيم ذوى الإعاقة إلى مجموعات تتشابه أو تختلف بنـاء على خاصية معينة، وتساعد على تحديد الطبيعة والمقدار ونـوع الخدمة التي تحتاجها كل فئة، وتتعدد التصنيفات والتسميات وفقا لمعايير ذاتيـة وطبية وتربويـة واجتماعية، وحسب الظهور في المراحل العمريـة المختلفة، وحسب طبيعة الأسباب، وعلى أسـاس المظهر الخارجي للحواس. وقد أجمع العلماء على تصنيف الإعاقة على: الإعاقة العقلية 
ـ الإعاقة السمعية ـ الإعاقة البصرية ـ الإعاقة الحركية (الجسدية) ـ صعوبات التعلم -

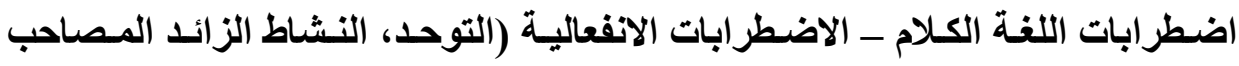

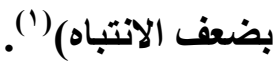
وتتنوع الإعاقات وتتحدد تصنيفاتها وأسبابها على النحو الآتي :-

ا الإعاقة العقلية:

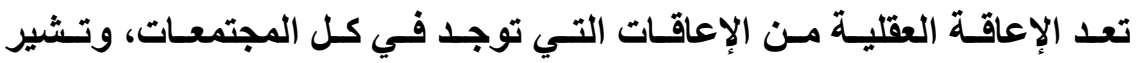

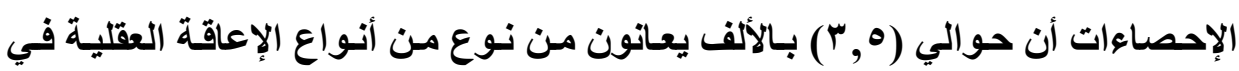
الفئة العمرية (من • 1 ـ ـ 1) سنة، وتزداد هذه النسبة لتصل حوالي († ) بـالألف في

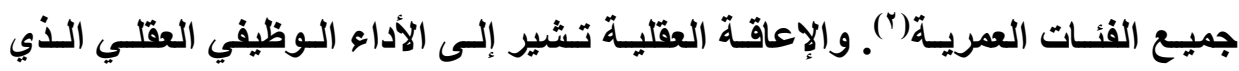
ينخفض عن المتوسط بمقار انحرافيين معياريين، ويصاحبه عجز في السلوك الكيفي تظهر آثاره منذ الولادة حتى سن النضج، ووفقا لتعريف الجمعيـة الأمريكية فإن هنـاك جـانبين لمعرفة مـن هو الإنسان ذو الإعاقـة العقليـة وهمـا مستوى الذكاء والسلوك

\section{أسباب الإعاقة العقابة:}

يختلف علماء النفس وعلماء التربية الخاصة والطب النفسي وغيرهم في تحديد أسباب الإعاقة العقلية، وتثبير معظم الأبحاث والدراسات إلى أن الأسباب تتعدد فيما بين الوراثيـة والإصـابات والعوامـل الجسمية والأمر اض الدماغيـة، واضطرابات في إفراز

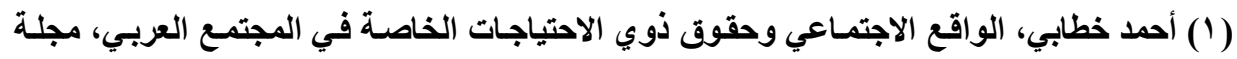

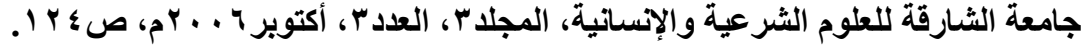

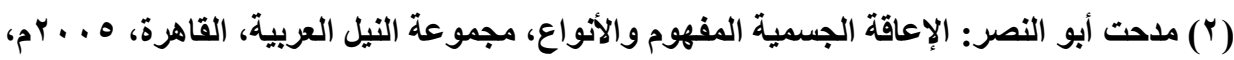

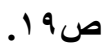

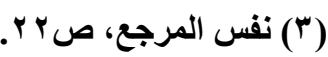


الغـدد الـصماء وأمـراض سـوء التفذيـة واضطر ابات الحمـل والـولادة والعوامـل البيئة

والحالة التفسية للام أثناء الحمل(').

وهنـاك تصنيف أخر لأسباب الإعاقة العقليـة والذي ينحصر في ثُلاث أسبباب

(أ) أسباب مـا قبل الولادة Penatal Causes : وتتحصر في العوامل الجينية، الأمر اض التي تصيب الأم الحامـل، كبر حجم الجمجمة، صغر حجم الجمجمـة، التعرض للإثـعاعات، العقـاقير والأدويـة، حـالات تـسمم البلازمــا، اضطر ابات الأيض والتغذيـة، تلوث الهواء والمـاء، اختلاف العامـل الريزيسى، الإصـابات،

$$
\text { الأورام الخبيثة. }
$$

(ب) أسباب أثناء الولادة Perinatal Causes، وتتضمن: الولادة العسرة، التهاب السحايا، الصدمات الجسدية، الولادة المبتسرة.

(جـ) أسـباب مـا بعـ الـولادة Postnatal Causes، وتتضمن: سـوء التغذيـة، الالتهابـات والأمسراض، نقـص اليـود، نقـص الأكسجين بعـد المـيلاد، التسمم بالملوثات، أمراض المخخ الثديدة. تصنيف الإعاقة العقلية:

تصنف الإعاقة العقلية حسب الأسباب إلى إعاقة عقلية أولية وثانويـة، وكذلك تصنف بحسب نسبة الأكاء إلى أربعة أقسام (r):

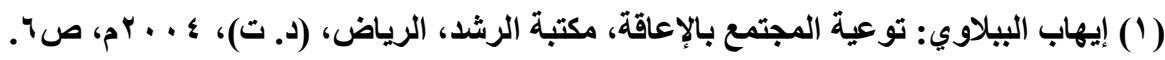

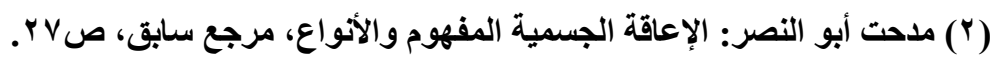

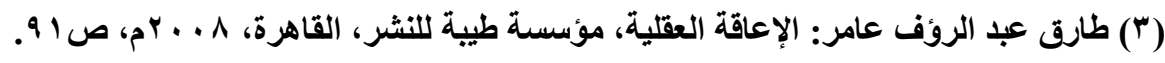


ـ الأول: الإعاقة العقلية البسيطة وتتراوح نسبة ذكائهم من ( • ـ ـ9 7)، وتسمى هذه الفئة بالقابلين للتعلم. ـ - الثني: الإعاقة العقلية المتوسطة وتتراوح نسبة نكائهم من (ه - 9 ـ )، وتسمى هذه الفئة بالقابلين للتبريب. ـ الثالث: الإعاقة العقلية الثديدة وتتراوح نسبة ذكائهم من ( • - ع ب). ـ الرابع: الإعاقة العقلية الثديدة جدا وتكون نسبة ذكائهم أقل من (9 ( ) درجة وذلك على مقياس ستانفورد - بينية أو وكسلر - بلفيو للاككاء.

r - r الإعاقة السمهمية: الإعاقة السمعية Hearing Impairment مصطلح عـام يغطى مدى واسـع

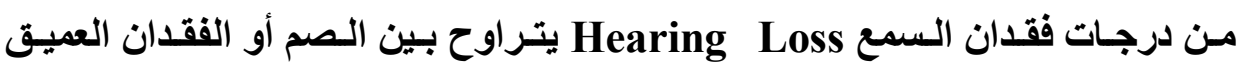
Mild Profound Deaf Hearing "سهير خيري" أن مصطلح الإعاقة السمعية مصطلح يدل على الإعاقة السمعية التي يتراوح مداها من فقدان سمعي خفيف Mild مروراً بفقد السمع المتوسط Meafness وضعيف السمع Hard of Hearing، والاختلاف بينهمـا يكون في طبيعة الإعاقة ونوع الخدمات التعليمية التي يجب تقديمهاب(؟).

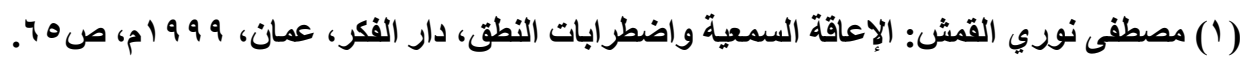

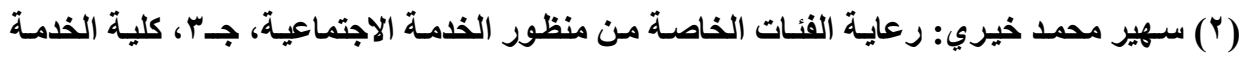

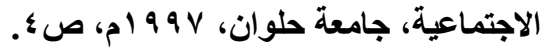


وهنا يمكن القول أن الأطفـال الأسوياء قد تحمل الكلمـة لـيهم أكثر من مدلول، لكن الطفل الأصم يلرك الكلمة بمدلول واحد أو رمزاً واحدا فقط لشيء واحد بمـا يؤدى إلى عرقلة وصعوبة نمو مهارات التواصل لايه، فبدون شكك أن حاسـة السمع الحيويـة لممارسة الخبرات اليومية، والتكيف الاجتماعي وأيضا الانفعالي للفرد.

\section{تصنيف الإعاقة السمعية:}

ليس من السهل تحديد مستويات الإعاقة السمعية بـالطرق العادية دون الاعتمـاد على أخصائي السمعيات والذي يعتمـ على وحدة قيساس السمع (ديسييل)، ويمكن تصنيف الإعاقة السمعية كما يلي ('):

1- الفترة العمرية التي حلثت فيها الإعاقة السمعية. r- موقع الإعاقة السمعية (توصيلية ـ حس عصبية ـ إعاقة سمعية مركزية ـ إعاقة سمعية مختلطة).

r- شدة الإعاقة السمعية ويمكن قياسها من خلال المقاييس السمعية لتحديد عتبة الصوت من خلال مـا يسمى بالوحدات الصوتية لقيساس مدى حساسية الأذن للصوث.

\section{أسباب الإعاقة السمهمية:}

تتعدد أسباب الإعاقة السمعية بين الأسباب الوراثية والمكتسبة، وأسباب متعلقة بمرحلة مـا قبل الميلاد وأثناء الميلاد ويعد الميلاد، فالإعاقة السمعية الوراثية تكون نتيجة انتقال بعض الحالات المرضية من الآبـاء إلى الأبنـاء من خلال الكروموسـومات (1) عبد المطلب القريطي: سيكولوجية ذوي الحاجـات الخاصـة وتربيتهر، طץ، دار الفكر العربي،

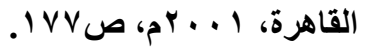


الحاملة لهذه الصفات مثل ضعف الخلايـا السمعية أو العصب السمعي، وتزداد حالات الإعاقة السمعية في حالـة زواج الأقـارب. وقد يكون للبيئة دوراً واضـحاً في الإصـابة بالإعاقة السمعية مثل: إصـابة الأم والطفل ببعض الأمـراض مثل الحصبة الألمانيـة، وكذلك تنـاول العقاقير أثنـاء الحمل أو تنـاول الطفل لبعض المضادات الحيويـة، كذلك الحوادث والضوضاء المستمرة المزعجـة والعوامل الولاديـة من شـأنها أن تؤثر على حاسة السمع لاى الإنسان (') - (1)

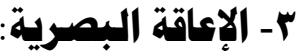

تعددت المصطلحات الدلالـة على الإعاقـة البصرية مثل: (الأعمى، الـضرير، الكفيف، فاقدي البصر، وضعاف البصر)، وتتراوح الإعاقة البصرية بين العدى الكلى الإلى والجزئي، وعلى هذا الأسساس يوجد نوعان من الإعاقة البصرية الأول وهم المكفوفون (العميان)، وهؤلاء تتطلب حالتهم البصرية استخدام طريقة برايل، والثاني هم ضعاف

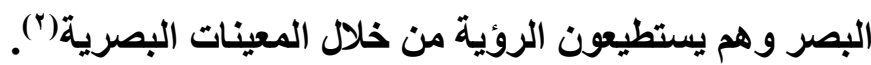

\section{تصنيف الإعاقة البصرية:}

توجد تصنيفات مختلفة للإعاقة البصرية منها("): 1ـ تصنيف الإعاقة البصرية من حيث الارجة، وتتضمن: مجموعة الإعاقة البصرية الكلية، مجموعة الإعاقة البصرية الجزئية.

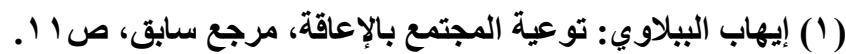

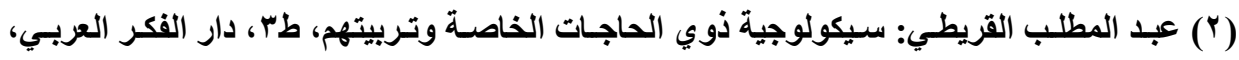

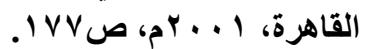

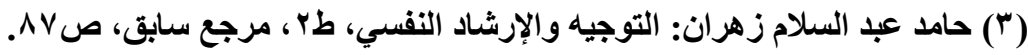


r ـ تصنيف الإعاقة البصرية من حيث السبب، وتتضمن: مجموعة أسباب مـا قبل الولادة وأثنائها مثل: (العوامل الجينية، والأمراض المعديـة، والحصبة الألمانية، العقاقير، تعرض الأم الحامل للأشعة السينية، ومن أمثلتها: حالات قصر النظر وطول النظر وولادة الطفل كفيفاً كلياً أو جزئياً) مجموعة أسباب مـا بعد الولادة وتتمثل في العوامل البيئية والثخصية مثل: (التقدم في العمر، سوء التغذيـة،

$$
\text { الحوادث، الأمراض إصابات العين). }
$$

r- تصنيف الإعاقـة البصرية من حيث القدرة على الإبصار طبقا لمقيـاس سـنلن،

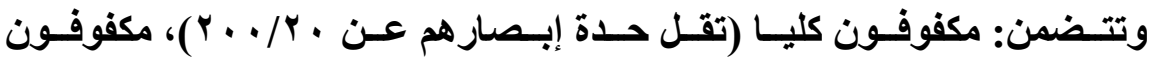

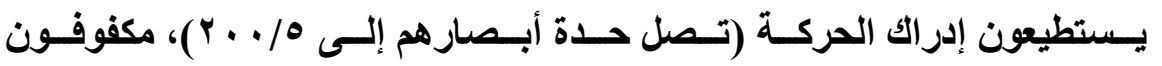
يستطيعون القراعة (تصل حدة إبصار هم إلي • // . . ץ)، مكفوفون يستطيعون

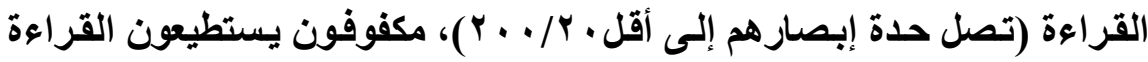

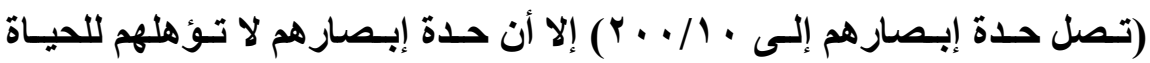
اليومية.

ـ ـ تصنيف الإعاقة البصرية من حيث النوع، وتتضمن: طول النظر، قصر النظر، صعوبة تركيز النظر، الاستجماتيزم، التهابات القرنية، الحول، تحرك العين، عمى

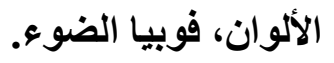
ع- الإعاقة الهركية (الجسدية): يرى بعض العلماء أنها ناتجة عن عيوب بذنية أو جسمية، هذه العيوب متعلقة بالعظام والمفاصل والعضلات، ويطلق على الشخص المصاب بمثل هذه العيوب معاق 
بدنياً أو حركياً' ')، ويرى فريق آخر أن المعـاق حركياً هو الشخص الذي لايـة عـائق جسدي يمنعه من القيام بوظائفه الحركية، وذلك لأسباب وراثية أو مكتسبة(؟).

\section{تصنيف الإعاقة المركية:}

اختلفت الآراء حول تصنيف الإعاقـة الحركية، فقد تكون الإعاقة خلقية، مثل الثلل الدماغي، أو مكتسبة بسبب أمراض أو إصـابات بعد الولادة، وقد تكون بسيطة ويمكن علاجها، وبعضها شديا مثل: ضمور العضلات والصرع وشلل الأطفال وتصلب الأنسجة العصبية، ويمكن تصنيف الإعاقة الحركية إلى الفئات التالية(")" • المصابون باضطر ابات تكوينية وهم من توقف نمو الأطر اف لايهر. • المصابون بشلل الأطفال وهم المصابون في الجهاز العصبي. • المصابون بالشلل المخي وهو اضطراب عصبي يحدث بسبب الخلل يصيب بض مناطق المخ. • المعاقون حركياً بسبب الحوادث والحروب والكوارث الطبيعية وإصابات العمل.

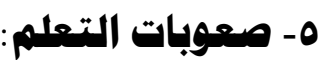

تعد صعوبات التعلم من الموضوعات الحديثة نسبياً في التربية الخاصـة، نظراً لاهتمام التربويين والآبـاء بمشكلات أبنـائهم التعليمية والتي لا يمكن تفسيرها بوجود

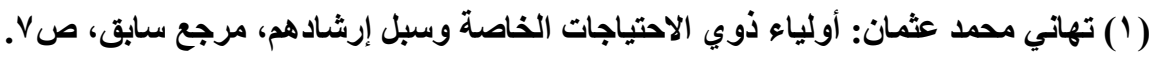

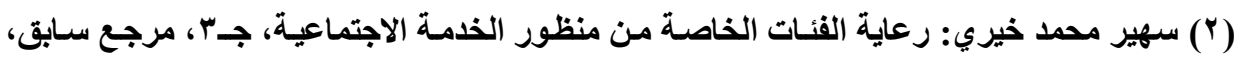

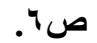
(r) سهير محمد خيري: رعاية الفئات الخاصة من منظور الخدمة الاجتماعية، جـَّ، مرجع سـابق،

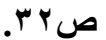


إعاقـات عقليـة أو حسية أو انفعاليـة أو جسمية أو صـية ولا يعـانون مسن مسشكلات نفسية، ومع ذلك فهم غير قادرين على تعلم المهارات الأسساسية مثل الانتباه أو الإدراك أو التذكر أو القراعة والكتابة، ويكون مستوى تحصيلهم اقل من أقرانهم ('). ويرجع الفضل في تعريف مفهوم صعوبات التعلم إلى عالم النفس الأمريكي كيرك Kirk والذي أوضح أن هذا المفهوم يستخدم لوصف مجموعة من الأطفال لديهم ضعف في النمو

اللغوي والتهجي والقراعة والمهارات اللازمة للتفاعل الاجتماعي().

كمـا تعرف صـوبات التعلم النمائيـة بأنهـا: اضطر اب في العمليـات العقليـة أو النفسية الأسساسية مثل: الاتتباه والإدراك وتكوين المفهوم والتذكر وحل المشكلات، كمـا يظهر ذلك في عدم القدرة على القراعة والكتابـة والحساب، ومـا يترتب على ذلك من قصور في تعلم المواد الدراسبة المختلفة(").

\section{أسباب صعوبات التعلم: - أنم:}

مـا تزال أسباب صعوبات التعلم غير واضحة على اختلاف أشكالها التربويـة

$$
\begin{aligned}
& \text { والطبية وغيرها، وتنقسم هذه الأسباب إلى عدة أسباب منها(؛): } \\
& \text { 1- الأسباب الوراثية (الجينية). } \\
& \text { r- الأسباب العضوية والبيولوجية. }
\end{aligned}
$$

(1) بطرس حافظ بطرس: صعوبات التعلم، القاهرة، حورس للطباعة و النشر، 999 99 م، ص ا V.

(2) Kirk, S., \& Chalfant , J. (1984): Developmental and academic learning Disabilities . Denver : Liove Publishing.

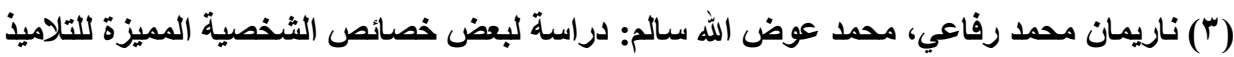

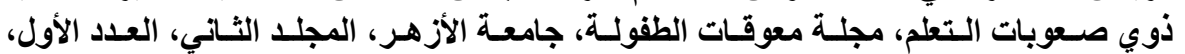

$$
\text { . }
$$

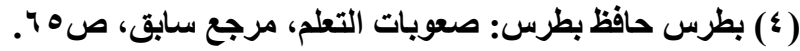




$$
\begin{aligned}
& \text { r- الأسباب البيئية. } \\
& \text { ع- الأسباب النفسية. } \\
& \text { 0- الأسباب التربوية. } \\
& \text { أنواع صهوبات التعلم: }
\end{aligned}
$$

أثدارت الاراسات في المجالات التربوية والنفسية والعصبية إلى تقسيم صعوبات التعلم إلى قسمين أساسيين هما: صعوبات التعلم النمائية وصعوبات التعلم الأكاديمية، وينـدرج تحـت كـل منهمــا عددا مـن الـصعوبات فمـن أنـواع صـعوبات التعلم النمائيـة (صسوبات الانتبـاه والإدراك والـذاكرة والتفكير واللغـة) ومسن أنـواع صسعوبات التتعلم الأكاديمية (صعوبات الكتابة والقراءة والحساب)(').

1- اضطرابات اللغة والكلام:

تعتبر اللغة وسيلة مهمة لتحقيق الاتصال الاجتماعي والتعبير عن الأت ووسيلة

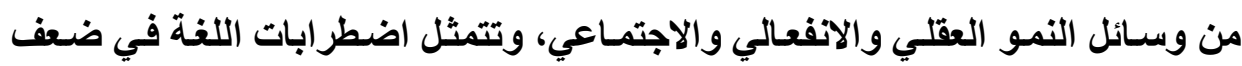
القدرة على التعبير، وهذا ما يطلق عليه تأخر نمو اللغة، أما اضطرابات الكلام تظهر في صـور متعددة مثثل الإبـال والحذف والتلعثم، كمـا أن اضطرابات اللفـة تتعلق باللغـة نفسها، من حيث وقت ظهورها أو تأخرها، أو سوء تركيبها من حيث معناهـا وقو اعدها

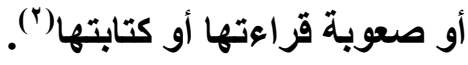

(1) فتحي مصطفي الزيات: صعوبات التعلم: الأسس النظرية والتثخيصية والعلاجية، دار النشر للجامعات،

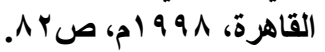

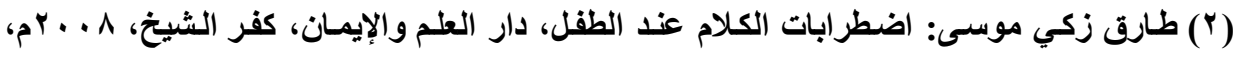




\section{أنواع اضطرابات اللغة والكلام:}

تتعدد مظاهر اضطر ابات اللغة بتعدد الأسباب وعلى هذا الأسـاس يمكن تقسيم

$$
\text { الاضطر ابات اللغوية إلى ما يلي ('): }
$$

$$
\text { 1- اضطر ابات النطق وتثنمل الحذف والإبدال والإضافة والتشويه. }
$$

r- اضـطرابات الـصوت ومنهـا انخفـاض أو ارتفــاع الـصوت، والبــة الـصوتية

$$
\text { والخنف. }
$$

r- اضطرابات الكلام ومنها التلعثم في الكلام وتظهر في صورة التكرار أو الإطالة

$$
\text { للحروف أو الكلمات وكذلك السرعة الزائدة في الكلام. }
$$

عـ اضطر ابات اللغة ومنها تأخر نمو اللغة وفقدان القدرة على فهم اللغة وهى مـا يطلق عليها الحبسة الكلاميـة ومنها صعوبات فهم الكلمـات والجمل والقراءة

$$
\text { والكتابة والتعبير. }
$$

\section{أسباب اضطرابات اللغة والكلام:}

تتعدد أسباب اضطرابات اللغة وتختلف باختلاف الحالات والفئة العمرية، وترتبط الاضطر ابات اللغويـة والكلاميـة بأسباب عضوية أو نفسية وأخرى اجتماعية وتربويـة 
يعد موضوع الاضطر ابات السلوكية من الموضوعات الحديثة في مجال التربية

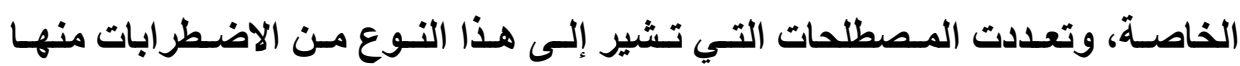
الاضطر ابات الانفعالية والإعاقة الانفعالية والاضطرابات السلوكية، وكل هذه المسميات

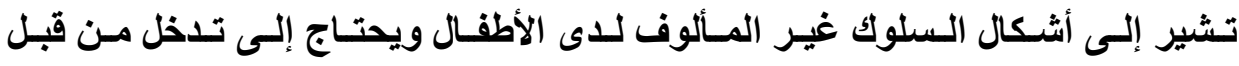
المختصين في مجال علم النفس والتربية الخاصـة والطب النفسي...، ويميل الباحثّن إلى استخدام مصطلح "اضطرابات السلوك"، لأنه أعم وأشمل ويضم أنواعـاً كثيرة من أنمساط السلوك"' . وتشير اضطر ابات السلوك إلى الاعتداء المستمر على الآخرين أو الخروج على قيم المجتمع كالسلوك العدواني والسرقة وإيذاء الذات المتكرر والعنـاد وعدم الثبات الانفعالي والنشاط الزائد والتوح(؟).

\section{أسباب الاضطرابات السلوكية:}

لقد تعددت الآراء التي تفسر أسباب الاضطرابات السلوكية، حيث يرى فريق أنها ترجع إلى أسباب بيولوجية مثل فصام الطفولـة وإصـابات الدماغ، وفريق آخر يرجعها إلى أسـباب بيئبـة مثـل نمـط العلاقـة بـين الأب وألام والطفل ونمـط التـشئة الأسـرية، والفريـق الثالــث يـرى أن العوامـل البيولوجيـة والبيئيـة لهــا أثـر كبيـر فـي إحـداث الاضطر ابات السلوكية("). وفيـا يلـي نعرض لأهـم أنـواع اضطر ابات النمـو الشـاملة وأكثرها انتشار في السنوات الأخيرة وهو اضطراب التوحد لاى الأطفال.

(1) أحمد الزعبي: الأمراض النفسية والمشكلات السلوكية والدراسية عند الأطفال، دار زهران للنشر،

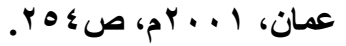
(Y) محمد الثنداوي: نظريات الإرشـاد والعلاج السلوكي، دار غريب للطباعة والنشر، القاهرة،

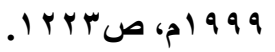
(r) (r) نفس المرجع، صبr) 


\section{التوحد Autism: (التود}

يعبر هذا المفهوم عن حالة اضطراب عقلي يصيب الأطفـال ويـل على الانغلاق

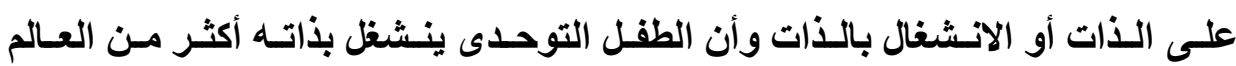
الخارجي، وهو اضطراب انفعالي في العلاقات الاجتماعية مـع الآخرين، ويتسم الطفل التوحدى بعدم الاهتمام بالآخرين وينسحب داخل ذاته('). كما يعرف التوحد بأنة "إعاقة تطوريـة متعددة تتضمن قصور في التواصسل الاجتمـاعي وضسعف في اللغـة والقيـام

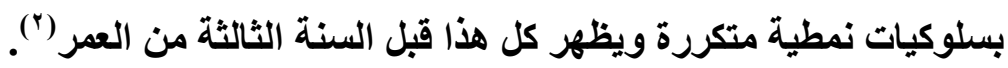
ويطلق على هذا الاضطراب الذاتوية، وانغلاق الذات، والاوتيستيك، والاوتيزم، وتظهر أعراضه في صورة نقص في النشاط التخيلي واضطراب الكلام وضعف الانتبـاه والانسحاب الاجتمـاعي وتجنب الآخرين والعدوان والتبلد الانفعالي، وتجنب الاتصال المباشر بالعين مع الآخرين والقيام ببعض اللازمات الحركية واللعب الروتيني النمطي

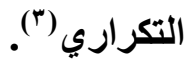

\section{أسبـابـاب التتوحــد}

منذ الأربعينات ظهرت نظريات لتفسير أسباب التوحد، وكان التركيز على علاقة الوالدين بطقلهمـا، ثم اتجهت التفسيرات نحو التركيز على العوامـل البيولوجية، كمـا أشـارت الدراسـات العلميـة إلى أن التوحد حالـة يعـاني منهـا الأطفـال مـن كافـة الفئـات

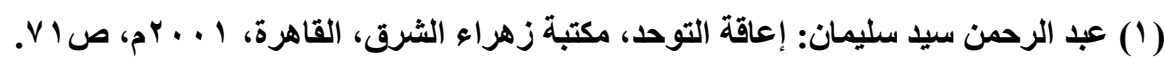
(ץ) عادل عبد الله محمد: الأطفال التوحدين: دراسات تثخيصية ويرامجية، مكتبة دار الرشاد، القاهرة، (t)

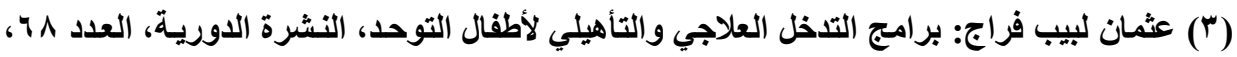

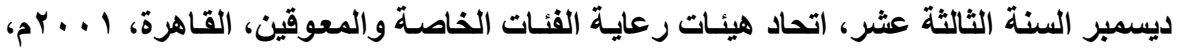


الاجتماعية، وأن الأكور أكثر إصابة من الإنـاث بحوالي ثلاثة أو أربعة إلى واحد، كمـا

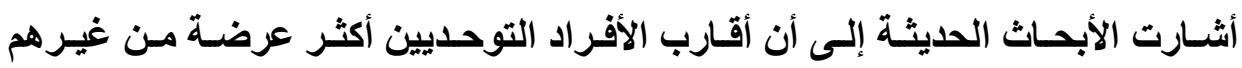
للإصـابة بـأعراض التوحد(') ومن بين أسباب التوحد الاضطرابات البيوكيميائية في بعض الإفرازات المخيـة وموجـات المـخ الكهربائيـة والتي تـؤثر على الأداء الـوظيفي للمـخ، كذلك انخفاض نشاط النصف الكروي الأيسر للمـخ والتنشئة الاجتماعيـة غير

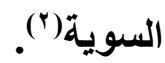

(1) عـادل عبد الله محمد: مقيـاس جيليام التقديري لتشخيص اضطراب التوحد، مكتبة دار الرشـاد،

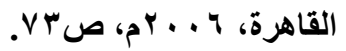
(Y) عبد الرحمن سيد سليمان: إعاقة التوحد، مرجع سابق، ص ؟ ؟ 9. 


\section{المبحث الثاني \\ هفهوم جرم الاتجار بالبشر}

إن تحديد مفهوم الاتجـار بالبشر يقتضي الوقوف على تعريف جرم الإتجـار بالبشر وبيان أسباب ظاهرة الإتجار بالبشر ، وذلك من خلال الآتي :المطلب الأول :- تعريف جرم الإتجار بالبشر المطلب الثاني :- أسباب ظاهرة الإتجار بالبشر المطلب الأول :- تعريف جرم الإتجار بالبشر:يعرف جرم الإتجار بالبشر لغة واصطلاحا وفقا للآتي :-

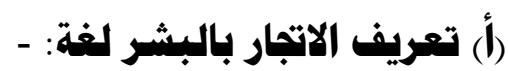

إذا كنا نقصد بالاتجار بالبشر بمعنى الرق وهو صورة من صور الاتجار بالبشر،

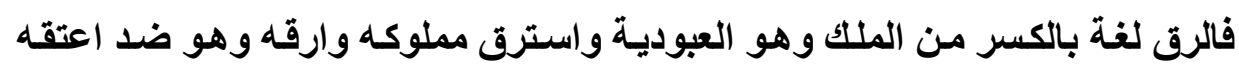
والرقيق المملوك واحد وجمع ومـراق البطن بفتح الميم وتشديد القـاف مـارق منـه(') ولأن الرق بالكسر الملك والعبودية وعن الإمام علي بن أبي طالب ـعلية السلامـ أنسه قال "يحط عنه بقر مـا عتق ويسعى فيمـا رق منـه". وكذلك في الحديث أن المكاتب عليه أن يؤدي بقدر ما رق منه ودية العبد ويقدر ما أدى دية الحر، ومعناه أن المكاتب إذا جنى علية جناية وقد أدى بعض كتابته فإن الجاني علية أن يدفع إلى ورثته بقدر ما 
كان أدى من كتابته دية حر ويدفع إلى مولاه بقدر ما بقي من كتابته دية عبد كان كاتب على ألف وقيمته (مائة ثم قتل وقد أدى خمسمائة فلورثته خمسة ألاف نصف) (') ـوأمـا إذا كنـا نقصد الاتجـار بالبشر بمعنـاه الشمولي فبوسعنا أن نبين أن معنى الاتجار هو الته

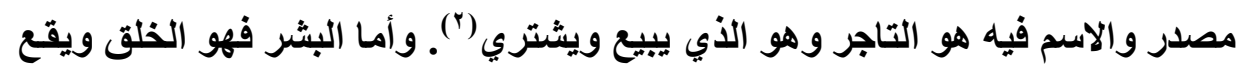
على الأنثى والذكر وعلى الواحد والاثنين والجمع ويقال هي وهو بشروهما وهي بشر (")

\section{(ب) تعريف الاتجار بالبشر اصطلاحا:-}

سوف نقسم هذه الفقرة إلى شقين حيث سنتناول في الثق الأول منها إلى تعريف فقهاء القانون لهذه الظاهرة، وأما في الثانية فسنتناول فيها تعريف المنظمات الدولية لهذه الظاهرة وكالاتي: 1 - تعريف الفقه القانوني لظاهرة الاتجار بالبشر: عرف جانبا من فقهاء القانون هذه الظاهرة بأنها كافة التصرفات المشروعة وغير المشروعة التي تحيل الإنسان إلى مجرد سلعة أو ضحية، يتم التصرف فيه بواسطة وسطاء محترفين عبر الحدود الوطنية بقصد استغلاله في أعمال ذات أجر متلن أو في أعمال جنسية أو مشابه ذلك، وسواء تم هذا التصرف بإرادة الضحية أو قصرا عنها أو بأي صورة

( (1) محمد بن مكرم بن علي أبو الفضل ابن منظور، لسان العرب، جـ ـ (، باب الراء، بيروت، دار صـادر،

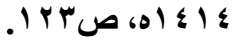
(Y) محمد بن محمد عبد الرزاق الزيدي: تاج العروس من جواهر القاموس، جـ ـ ال، تحقيق مجموعة من

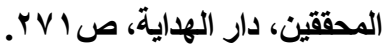

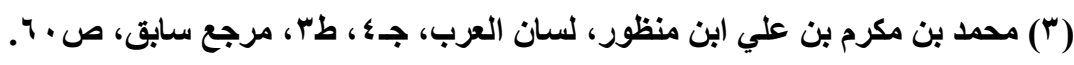


أخرى من صور العبوديـة(') ، وذلك تجسبيا لفكرة أن الحماية القانونية لذوي الإحياجات الخاصة تكون بنـع استغلال ما لليهم من عوز وعجز جسدي ونفسي وذلك من خلال وضع تشريعات منع الإتجار بالبشر.

r - وأمـا تعريف المنظمـات الدولية لهذه الظـاهرة: فبحسب مفهوم الجمعية العامـة لمنظمة الأمم المتحدة هي تجنيا أو نقل أو انتقال أو إيواء أو استقبال أفراد عن طريق التهديد واستخدام القوة أو صور أخرى كالإكراه أو الاختطـف أو الاحتيال

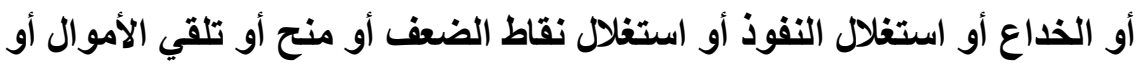

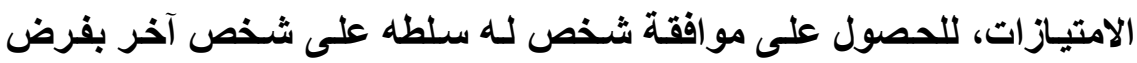
الاستغلال، ويشمل الاستغلال كحد أدني الدعارة أو صورا أخرى للاستغلال الجنسي أو العمالة أو الخدمة القسرية أو العبودية أو الممارسـات الشبيه بها أو الأشغال الثاقة أو انتزاع الأعضاع(`). r- ـ وأما تعريف هذه الظاهرة من وجهه منظمة العفو الدولية: بأنها انتهاك حقوق الإنسان بما فيها الحق في السلامة الجسدية والعقلية والحيـاة والحريـة وأمن الثخص والكرامة والتحرر من العبودية وحرية التنقل والصحة (والخصوصية

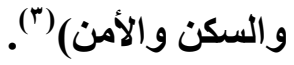

(1) سوزي عدلي ناثد: الاتجار في البشر بين الاقتصاد الخفي والاقتصاد الرسمي، منشورات الحلبي

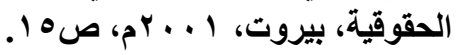

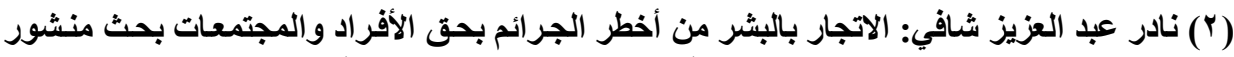

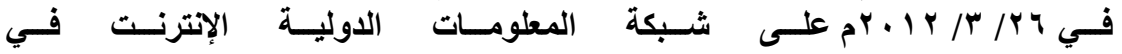
http://www.lebarmy.gov.ib/articale.asp

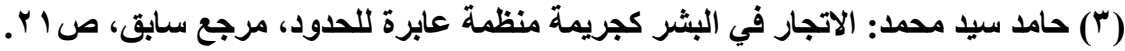


ع- في حين عرفتها المنظمـة القطريـة لمكافحة الاتجـار بالبشر : بأنها: عملية توظف أو انتقال أو نقل أو تقديم مـلاذ لأنـاس لغرض استغلالهم وتتضمن العملية القيام بأعمـال غير مشروعة كالتهديد أو استخدام القوة وغيرهـا من أثكال الإكراه أو الغث وأن هذا الاستغلال يتم من خلال إجبار الضحية على أي شكل من أشكال الاستغلال (الجنسية أو العبوديـة أو غيرها من الممارسـات المقربة للعبودية(') وذلك تجسيدا لفكرة أن الحماية القانونية لذوي الإحياجات الخاصة تكون بنـع استغلال ما لديهم من عوز وعجز جسدي ونفسي وذلك من خلال وضع تشريعات منع الإتجار بالبشر.

\section{المطاب الثاني :أسباب ظاهرة الإتجار بالبشر}

يمكن أن ترد هذه الظاهرة إلى طائفتين من الأسباب وعلى النحو الأتي:

\section{الفرع الأول :-الأسباب العاهة:}

$$
\text { ويندرج ضمنها مجموعة من الأسباب وأهمها ما يلي: }
$$

ـ أولا: الحروب والكوارث الطبيعية: يعتبر هذا الجانب من أبرزهـا، ويتضمن هذا الجاتب العديد من الأمور التي قد تدفع باتجاه المتاجرة بالبثر، مما يؤثر سلبا على كافة الجوانب الاجتماعية لما ستجره من فقز والتمسكك بـالعروض التي سرعان مـا يتبين عدم مصداقيتها كالوعود الكاذبة بالعمل والشراء، حيث يدفع البشر أنفسهم إلى هؤلاء التجار فالبعض منهم تم حجزهم وخطفهم وإجبارهم، ولكن هنـاك أيضا

(1) سوزي عدلي ناثد: الاتجار في البثر بين الاقتصاد الخفي والاقتصاد الرسمي، مرجع سـابق، 
الكثير منهم من يجد أن الاخول في هذا النوع من الأنواع قرارا وحلا لمشكلاتهم

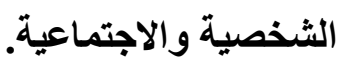

ـ ـ ثانيا:- عدم الاستقرار السياسي: حيث يعد عدم استقرار البلان من هذه الناحية

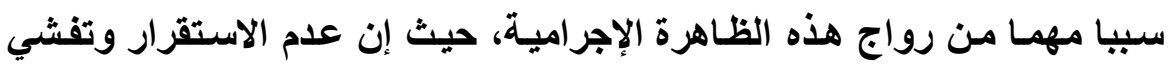
ظاهرة الإرهاب وما يتولا عنهما من كوارث بشرية، حيث سينتج عن ذلكت فئسات كثيرة من اللاجئين الفارين من المناطق المضطربة سياسيا والتي تثشل أناسا همها تحقيق الرفاهية بأبسط المعايير والابتعاد عن الحياة المرة والظروف الصعبة،

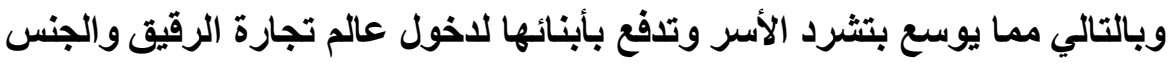

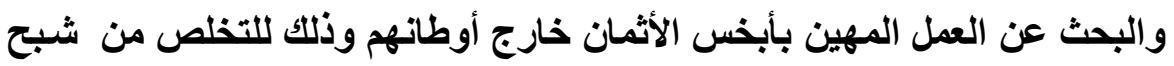
الموت والقتل وتوفير لقمة العيش لأسرهم ولمن يعولون مما يؤد إلى الهجرة إلى الهى

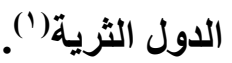
- ـالثا:- أسباب ديموغرافية: ومن أبرزها: عدم التوازن المتنامي بين الجنسين في مناطق جنوب وشرق أسيا يعزز بصورة متزايدة الطلب على ضحايا الاتجار

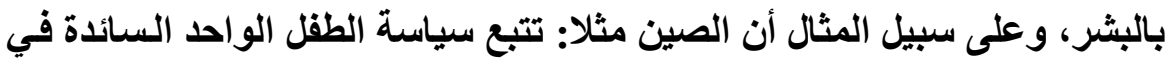

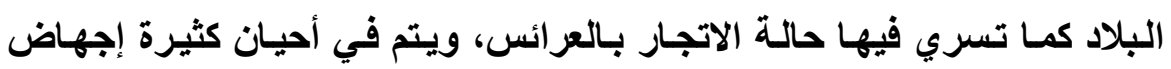
الفتيات، وقد وردت العديد من التقارير التي تؤكد أنه في بعض الحالات جرى قتل

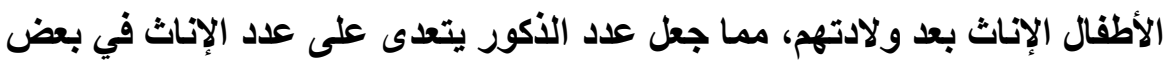

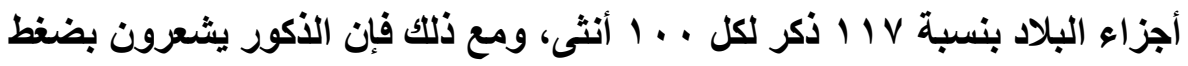

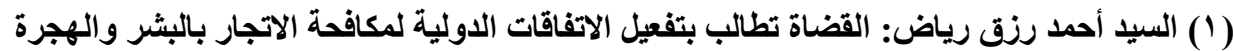

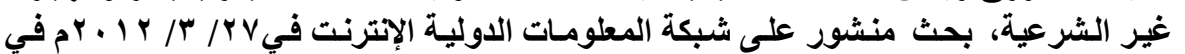

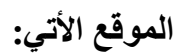
http://kadyonline.maktoobblog.com 
اجتماعي فيدفعهم إلى الزواج ممـا يجعل بعض اللذين لا يجدون فتيات صـالحات للزواج يحاولون شراء عرائس من منـاطق أخرى من البلاد أو من المنـاطق

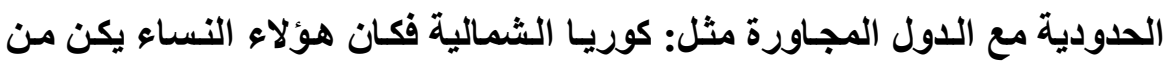
النساء اللاتي يبعهن أهليهن في أحيان كثيرة ويجبرون على الزواج أو ممارسـة البغاء أو العيش كخليلة سرية. والمنـاطق التي يتم فيها الاتجـار هي المنـاطق الاخلية للمقاطعات الصينية، أما بالنسبة للهند ففي بعض المنـاطق تعتبر الفتيـات أعباء اقتصادية بالنظر للمهر الأي يطلبه العرسان المحتملون، وتظهر إحصائيات الدولة وجود عدم توازن ملحوظ في بعض المنـاطق الرئيسة من البلاد وأن عدم وجود هذا التوازن بين الجنسين أدى إلى وجود الملايين من الأكور أكثر من الإناث في سوق الزواج، مما أوجد ضغط الزواج وضغطا على الرجال لإيجاد نساء يصلحن للزواج وكاتت نتيجة ذلك حصول بعض الحالات التي يتم فيها شراء أو خطف نساء من النيبال أو من بنغلادش ومناطق أخرى من الهند ليصبحن زوجـات في قرى قـ نسميها ب(قرى العازبين)، وهذا الخلل يساهم في إبراز طلب أكبر وأعظم على النساء والفتيات مما يحفز الطلب على ضحايا الاتجار بالبشر ('). - ويمكنتا القول بأن هزالة الوسائل الرقابيـة لاسبيما منهـا المفروضـة على أصحاب الأعمال وممارساتهم، الأمر الذي أدى إلى توسـع كثير من رجـال الأعمـال لنطاق تجارتهم لتشمل الاتجار بالبشر، ويتمثل ذلك في إعلان هؤلاء التجار عن رغبتهم في التعاقد مع أشخاص للعمل لمختلف المجالات وفي مقابل أجور خيالية، ومن ثم يصطام هؤلاء الأشخاص بالواقع وهو أنهم ما كانوا سوى وسيلة سهلة سقطوا في 
شباك تاجر خادع من ثم يعيثون الواقع الأليم القاسي عندما يجدون أن الأعمال

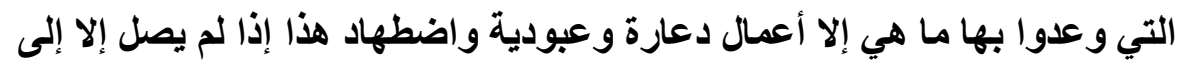

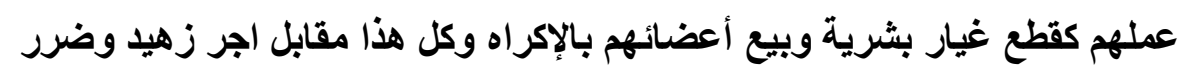
نفسي وجسد كبير على الضحية.

- ـ رابعا:- أسباب ضعف المؤسسات التعليمية:- ممـا ينظو عليه من انتشار الأمية

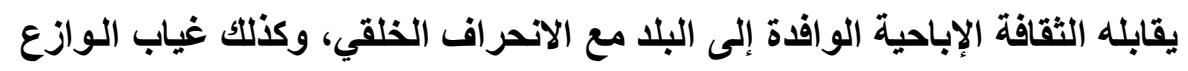
الايني مع قصر الأداء الناشئ لبعض أجهزة الاولة' (') - خامسا: عدم وجود قاعدة تثريعية متكاملة تأخذ على عاتقها معالجة هذه الظاهرة

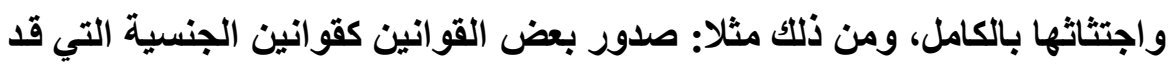

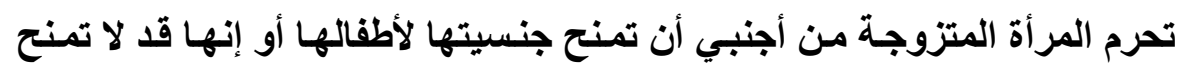

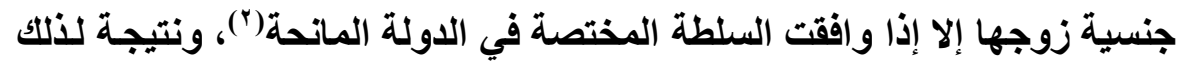

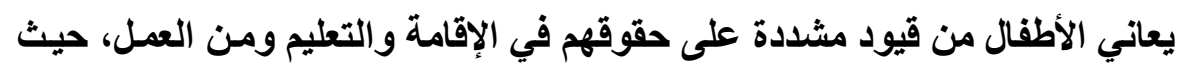

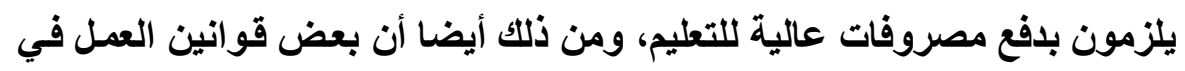

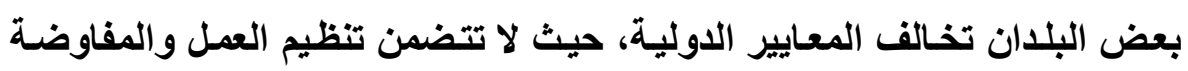

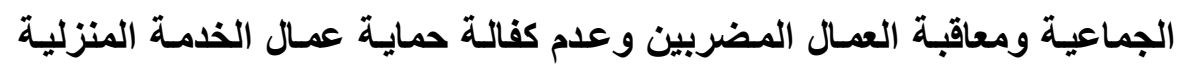

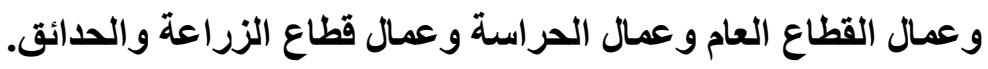

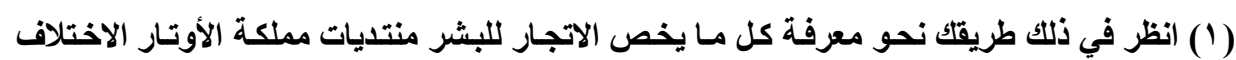

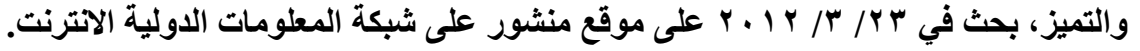

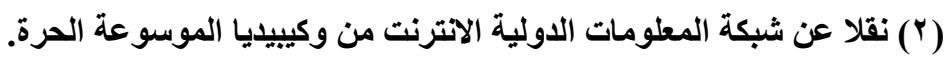
http://www.xzx4ever.com/showthread, 


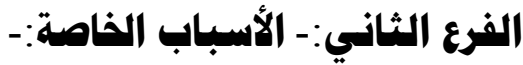

ويندرج تحت هذا الفرع جملة من الأسباب يمكن إيضاحها بالأتي:

ـ أولا: الرغبة في تحقيق الثراء السريع: من أهم أسباب هذه الآفة المعقدة التي

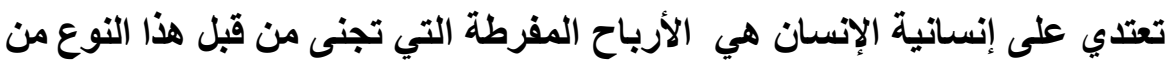

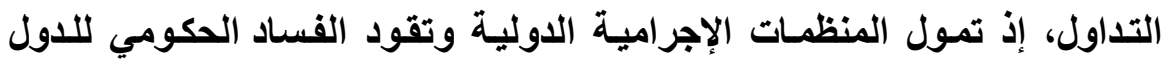

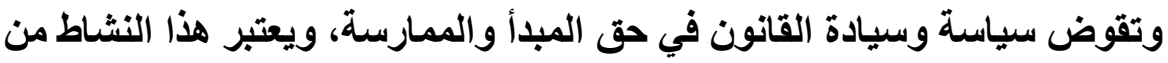

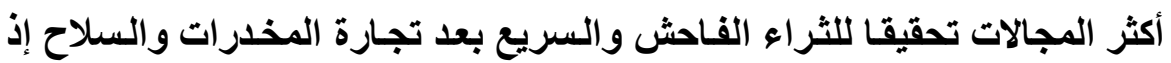

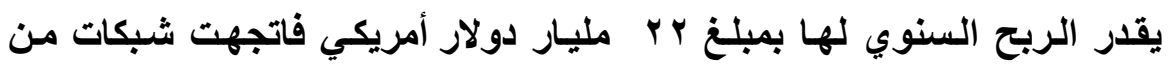

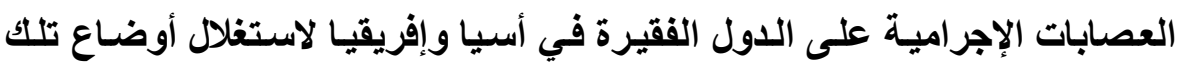

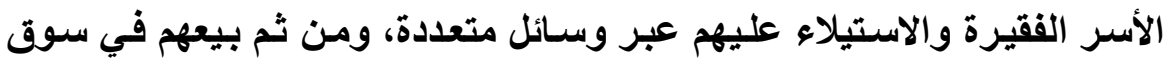
النخاسة كعبيد وبعد ظهور شبكة الإنترنت ساهمت في اتساع هذه الظاهرة عالميا، حيث ظهرث مواقع متخصصة تروج لمثل هذه الأعمال، ممـا أدى إلى انتشار هذه فئه الظاهرة بصورة ضخمة ومبهرة بالرغم من الجهود العملاقة التي تقوم بها الدولية ل لمكافحتها.

ـ ـ ثانيا: الفقر وسوء الحالة الاقتصادية: يعتبر الفقر العامل الرئيس للاتجار بالبشر ولكن ما العلاقة التي تجمع وتربط بين الفقر والاتجار بالبشر أن معظم حالات بيع

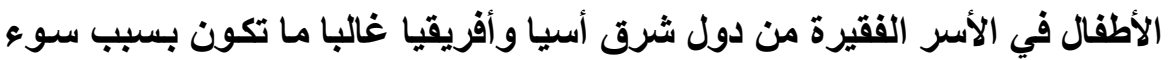
الظروف المعيثية أو انعدامها فما الذي يدفع تلك الأسر إلى تسليم أطفالها لتجار الرقيق وقيام أولادهم بالأعمال الوضيعة، وذلك بغية الحصول على دخل للمعيشة

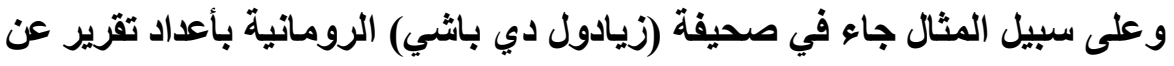

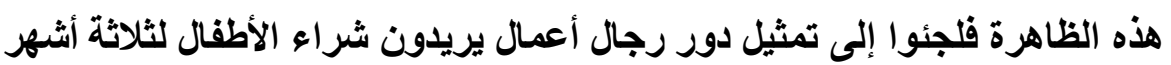


حتى يعملوا للديهم بجمع الطبخ فيأخذ الأهل مـالا مقابـل التنـازل عن أبنـائهم هذا التنازل الكبير والعظيم لابد أن يكون مقابل مبلغا طائلا من المال، لعل هذا ما اعتقده بعضهم ولكن في الحقيقية التنازل يكون في مقابل نقد يتراوح مابين ه ــ ـ • يورو فقط، والأدهش من ذلك والأكثر استغرابا أن بعض الأهـالي عرضوا عليهم الأطفـال مجانا ليوفروا على أنفسهم مهمة إعاشتهم وفي بعض الحالات الأخرى تقوم الأسر الفقيرة بإعطاء أطفالهم لبعض الأقارب وغير الأقارب اللذين يعدوهم بالتعليم ولكن يبيعونهم كعبيد للحصول على المال، ولعل الأدهى والأمر أنه يوجد سماسرة للاتجار بالأطفال، حيث ينتقل هؤلاء بين القرى الفقيرة يبحثون عن الأسر الأكثر فقرا وحاجة للمال فيعرض على تلك الأسر عرضا بسيطا من المال لتحسين حياتهم مقابل حصوله على طقلهم فيبقى الطقل يعمل لصالح السمسار حتى تقوم الأسر بالوفـاء بدينهم تجاه السمسار أو عمل الطقل فترة معينة حتى ينقضي دين ('). ـ ثالثا: البطالة وانتشار ها بثكل كبير وعدم قدرات الجهات الحكومية على إيجاد حلول لها أو معالجتها وبمعنى آخر قلة فرص العمل المتوافرة.

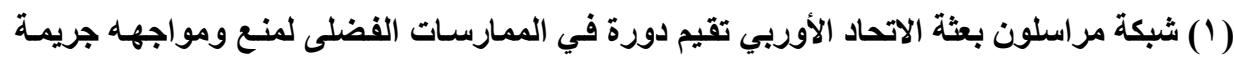

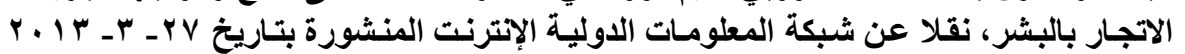

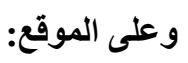

http://www.reportersnetwork.net/article 


\section{المبحث الثالث \\ واقع الحماية القانونية لذوي الإحتياجات الخاصة هن جرم الإتجار بالبشر في الأردن الأبيات}

يتضح واقع الحماية القانونية لذوي الإحتياجات الخاصة من جرم الإتجار بالبشر في الأردن من خلال مبدأ الإلتزام بتجريم ظاهرة الإتجار بالبشر في الأردن و نطاق الحمايـة القانونيـة لـذوي الإحتياجـات الخاصـة مـن جرم الإتجـار بالبشر في الأردن ، وللوقوف على هذا الواقع سنعالجه من خلال المطلبين الآتيين :المطلب الأول :- مبدأ الإلتزام بتجريم ظاهرة الإتجار بالبشر في الأردن المطلب الثاني :- نطاق الحمايـة القانونية لذوي الإحتياجـات الخاصـة من جرم الإتجار بالبشر في الأردن

المطاب الأول : هبدأ الإلترام بتجريم ظاهرة الإتجار بالبشر في الأردن حرص المشرع الأردني على تطبيق مبدأ الالتزام بتجريم الاتجـار بالبشر من خلال الآتي:-

الفرع الأول :- التزامهات الأردن الدولية وقيسمتها القانونية:

أكد القضاء الأردني على ضرورة المصادقة على الاتفاقيات الاولية حسب نص

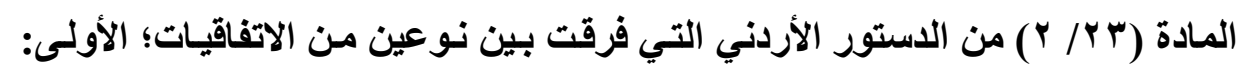
يترتب عليها تحميل خزانة الدولة شيئًا من النفقات أو مساس بحقوق الأردنيين العامـة 
أو الخاصة لا تكون نافذة إلا إذا وافق عليها مجلس الآمـة. والثانية: لا يترتب عليها

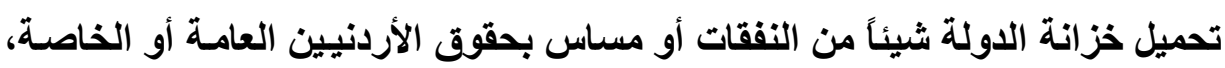

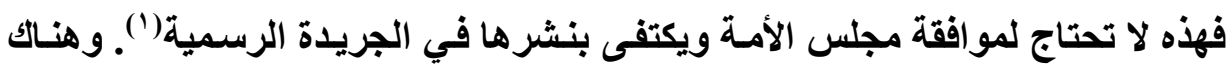

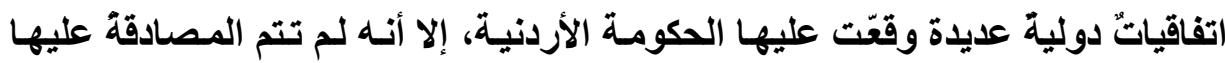

حسب الأصول الاستورية، لذلك اعتبرها القضاء غير نافذة على الصعيد الوطني(") ولم يتتاول الاستور القيمة القانونية للاتفاقيات الاولية المصادق عليها، إلا أن

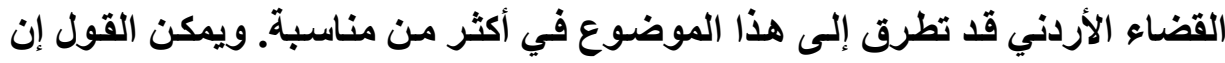

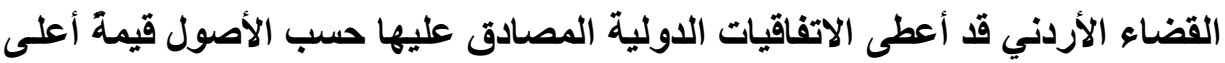

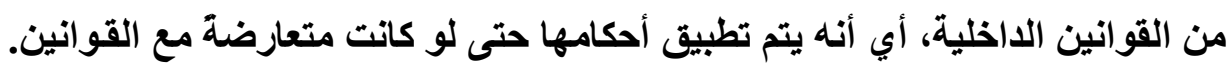

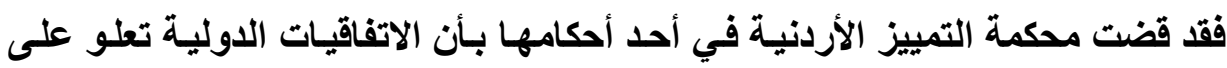

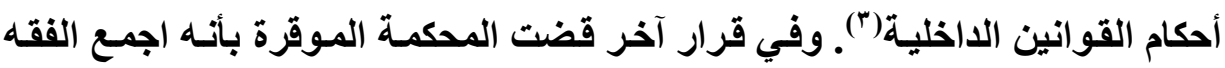

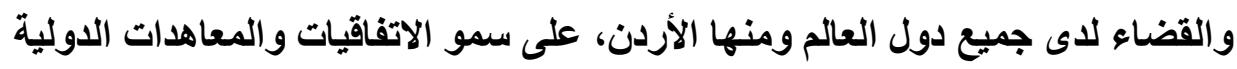

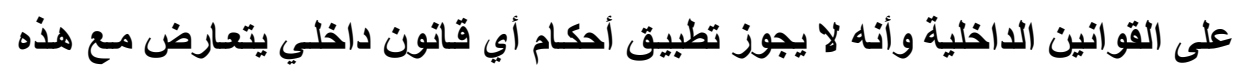

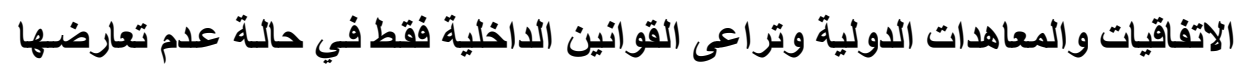

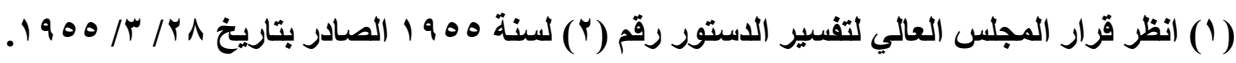

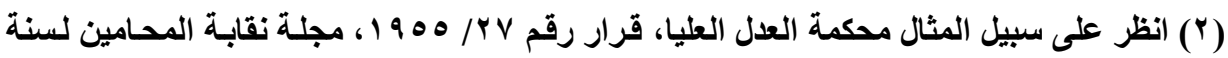

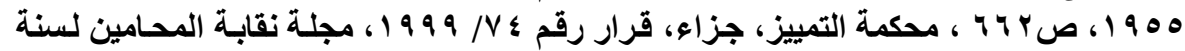

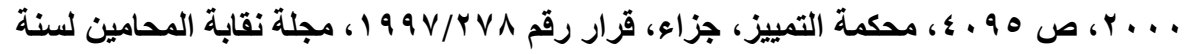

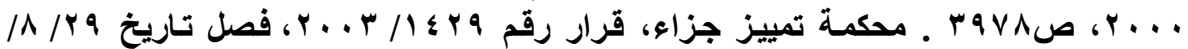

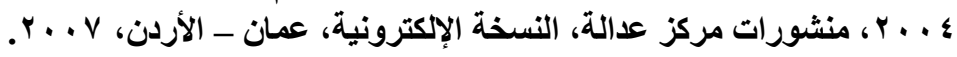

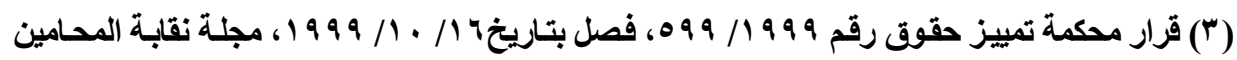

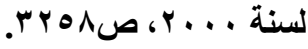


مع هذه الاتفاقيات والمعاهدات الدولية بحيث يمكن تطبيقهمـا معاً وهو مـا جرى عليه

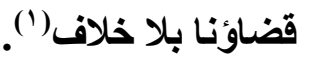

واعتمـاداً على ما تقدم يمكن القول من دون أدنى شك إن القضاء الأردني قد كرّس مبدأ سمو المعاهدات الدولية على قواعد القانون الداخلي، ويؤيده في ذلك الفقه الأردني ()؛ إذ أوضـح بعض فقهاء القانون على ضرورة تمتع المعاهدة بقوة تفوق القانون الاخلي، حرصاً على استقرار المعاهدات وتمسكاً بالالتزامات الدولية وصيانة لحقوق الأفراد التي نصت عليها المواثيق الدولية والتي توقع عليها الدول بإرادتها

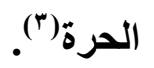

صادق الأردن على اتفاقيات حقوق الإنسان الأساسية باستثناء الاتفاقية الدولية لحماية حقوق جميع العمال المهاجرين وعائلاتهم لسنة ـ99 19 1، الأمر الذي يفقد الإطار القانوني لحماية العمال المهاجرين واحدة من أهم دعائمه. وفي مجال مكافحة الاتجـار بالبشر، فقد انضمت الأردن إلى الاتفاقية الدولية لمكافحة الجريمـة عبر الوطنية لسنة

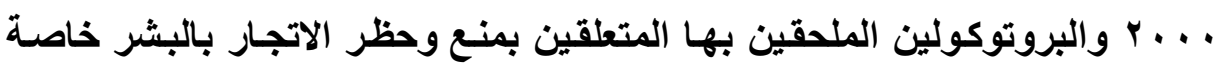
النساء والأطفال ومكافحة تهريب المهاجرين. وعلى صعيد قانون العمل الدولي، الأردن

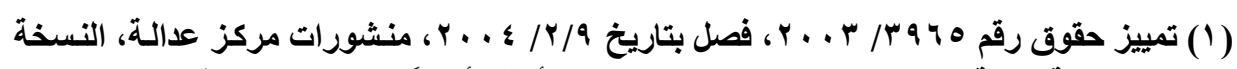

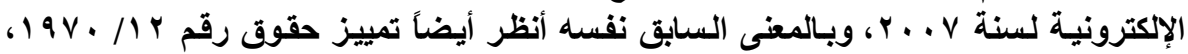

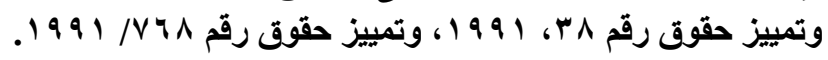

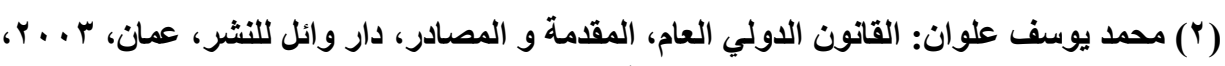

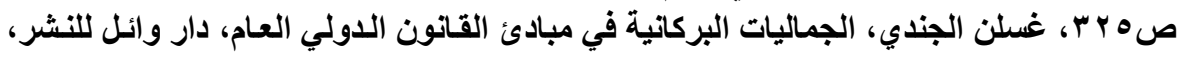

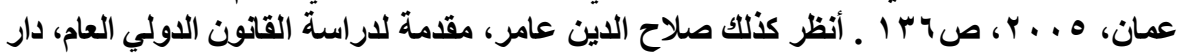

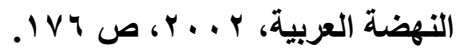

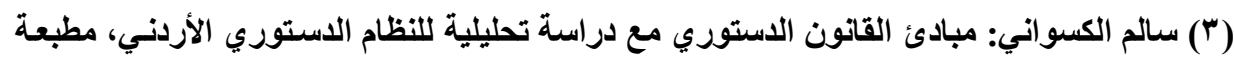

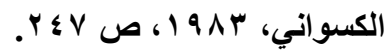


ملزم بإعلان منظمه العمل الدولية بشأن المبادئ والحقوق الأساسية في العمل الذي يلزم الدول الأعضاء، المصدقة أو التي لم تصدق بعد على الاتفاقيات ذات الصلة، كمـا أنه وقع على ؟ ب اتفاقية عمل دولية نشر منها في الجريدة الرسمية ؛ ا اتفاقية فقط،

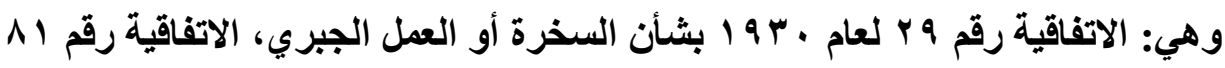

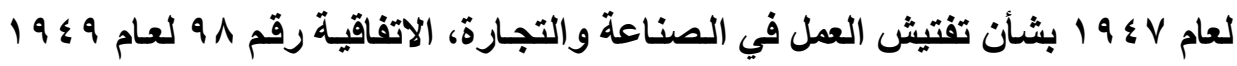

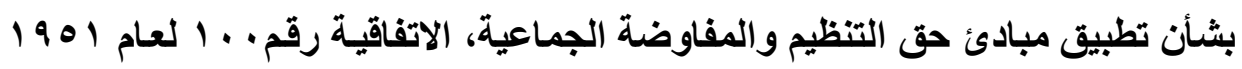
بشأن تساوي أجور العـال والعـاملات عند تساوي العمل، الاتفاقية رقم 111 العام 11 لعام 1901 بشأن عدم التمييز فيمـا يخص الاستخدام في المهن، الاتفاقية رقم 111 العام 11 لعام 19 19 بثأن المراجعة الجزائية للاتفاقيات التي بناها المؤتمر العام في دوراته السابقة بقصد توحيد النصوص الخاصة بإعداد مجلس الإدارة للتقارير عن سير الاتفاقيات، الاتفاقية رقم 11 ا لعام ب 19 ا بشأن المساواة في المعاملة بين الوطنيين وغير

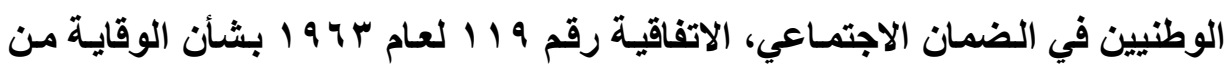
الآلات، الاتفاقية رقم • ب ا لعام ب7 19 بثأن الشروط الصحية في المنشآت التجارية

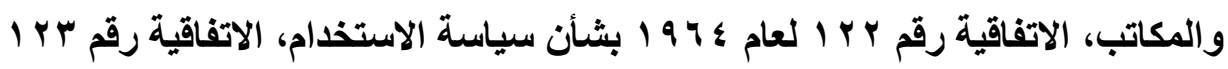
لعام ه 99 ابثأن السن الأدنى للقبول في العمل تحت الأرض بالمنـاجم، الاتفاقية رقم ع ب ا لعـام ه 197 بشأن الفحص الطبي الخـاص بلياقة الأحداث للعمل تحت الأرض

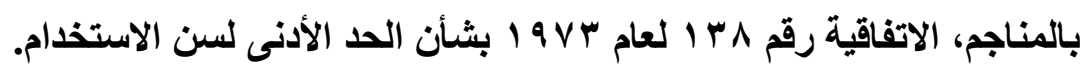

ولم يوقع الأردن حتى تـاريخ إعداد هذه الدراسـة على مجموعة من الاتفاقيـات

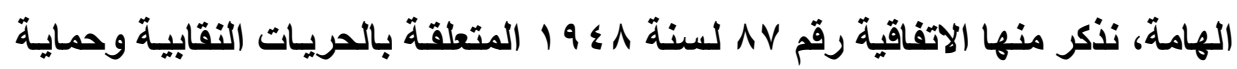
حق التنظيم واتفاقية رقم ^ه حول حق التنظيم والمفاوضـة الجماعيـة، واتفاقيـة رقم

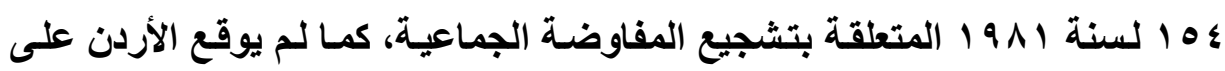

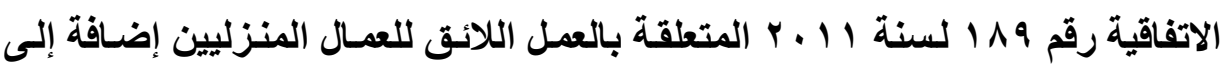


الاتفاقيات رقم q و و أ و والتي تتعلق بشكل مباشر بحقوق العمـال المهاجرين، وحماية العمال المهاجرين غير النظاميين.

\section{الفرع الثاني :- تجريم ظاهرة الاتجار بالبشر:}

سنداً لأحكام المادة r من برتوكول منع الاتجار بالبشر فإن من أهداف الاتفاقية هو "منع ومكافحة الاتجـار بالبشر، مـع إيـلاء اهتمـام خـاص للنساء والأطفـال"، ومن الأن

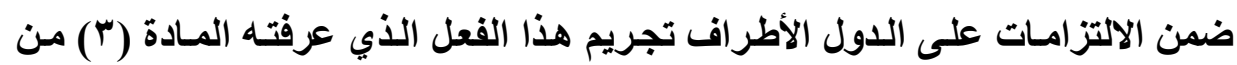
الاتفاقية، وأوضحت المادة (0) من البرتوكول أن الدولـة الطرف تلتزم باعتمـاد مـا قد يلزم من تدابير تثريعية وتدابير أخرى لتجريم الاتجار بالبشر، في حسال ارتكابه عمدا. واعتمـاد مـاقد يلزم من تدابير تشريعية وتـابير أخرى لتجريم الشروع في ارتكـاب جريمة الاتجار بالبشر، بالمساهمة كشريك بها أو تنظيم أو توجيه أشخاص آخرين لارتكابـه ، كون الحماية القانونية لذوي الإحياجـات الخاصـة تكون بنـع استغلال مـا للديهم من عوز وعجز جسلي ونفسي وذلك من خـلال وضسع تشريعات منسع الإتجـار بالبشر.

وانطلاقا من الالتزامات السابقة، قام الأردن بسن قاتون منع الاتجار بالبشر رقم

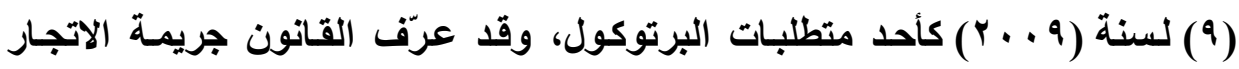
بالبشر من خلال المادة (r) على النحو التالي: (أ) لمقاصد هذا القانون تعني عبارة جرائم الاتجار بالبشر:1- استقطاب أشخاص أو نقلهم أو إيوائهم أو استقبالهم بغرض استغلالهم عن

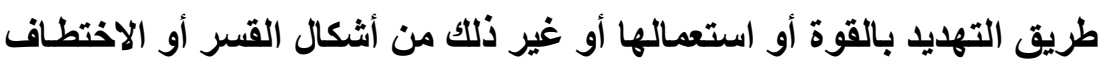
أو الاحتيال أو الخداع أو استغلال السلطة أو استغلال حالة ضسف أو بإعطاء 
أو تلقي مبالغ مالية أو مزايـا لنيل موافقة شخص لـه سيطرة على هؤلاء

$$
\text { الأشخاص و/أو }
$$

r- استقطاب أو نقل وإيواء أو استقبال من هم دون الثامنة عشرة متى كـان ذلك بغرض استغلالهم ولو لم يقترن هذا الاستغلال بالتهديد بالقوة أو استعمالها أو غير ذلك من الطرق الواردة في البند (1) من هذه الفقرة. (ب) لغايات الققرة (أ) مـن هذه المـادة تعنـي كلمـة (استغلال) استغلال الأثخخاص

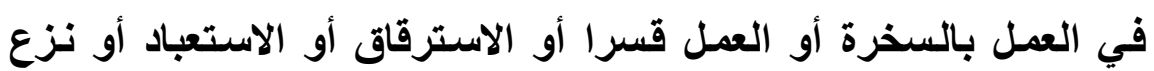
الأعضاء أو في الدعارة أو أي شكل من أشكال الاستغلال الجنسي. وتعتبر الجريمة ذات طابع (غير وطني) في أي من الحالات-: hBjdm

$$
\text { 1- إذا ارتكبت في أكثر من دولة. }
$$

r- إذا ارتكبت في دولة وتم التحضير أو الإعداد أو التخطيط لها أو الإشراف عليها

$$
\text { في دولة أخرى. }
$$

r- إذا ارتكبت في أي دولة عن طريق جماعة إجرامية منظمة تمارس أنشطة إجرامية

$$
\text { في أكثر من دولة. }
$$

$$
\text { عـ إذا ارتكبت في دولة وامتدت أثثارها إلى دولة أخرى. }
$$

يُلاحظ أن التعريف الوارد في القانون شديد الشبه بـالتعرف الوارد في

$$
\text { البروتوكول(')، مع وجود بعض الاختلافات. }
$$

$$
\text { (1) نصت المادة r منن البروتوكول على ما يلي: لأغراض هذا البروتوكول: }
$$

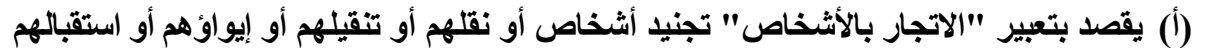

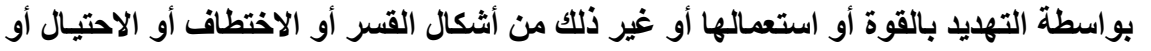
$=$ 


\section{المطاب الثاني : نطاق الحماية القانونية لذوي الإحتياجات الخاصة هن جرم الإتجار بالبشر في الأردن}

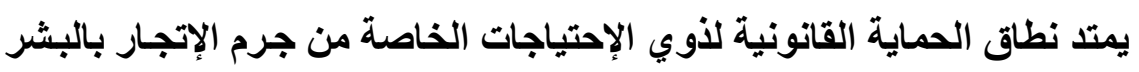

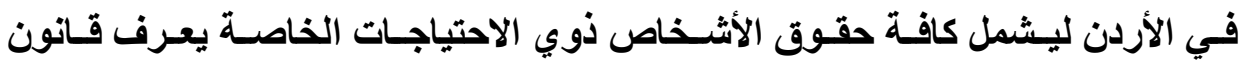

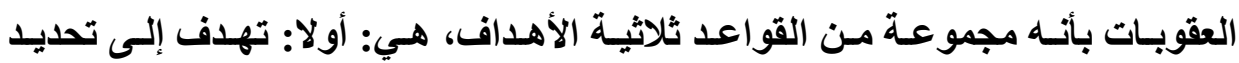
وتجريم التصرفات التي تشكل جريمـة وثنانياً: إلى تحليد الأثشخاص الذين يتحملون المسئولية عن ارتكاب الجرائم وثالثًا إلى تحديد مقدار العقوبة المترتبة على ارتكاب كل

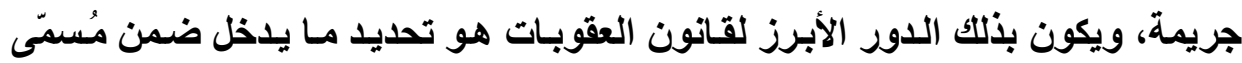

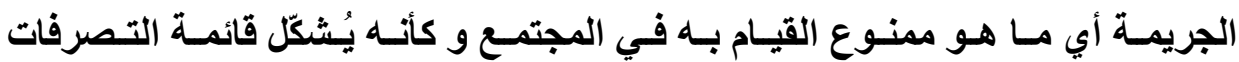
المخظورة إضافة إلى القواعد التي على أساسها تترتب المسئولية الجنائية. ويهدف قانون العقوبات إلى معاقبة تصرف كان سبق ارتكابه زمنياً أن اعتبره

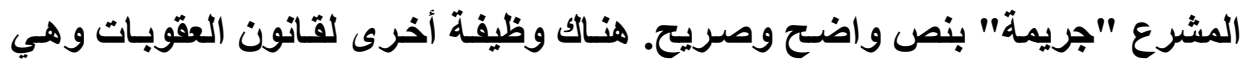

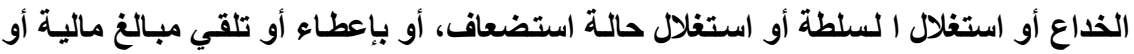

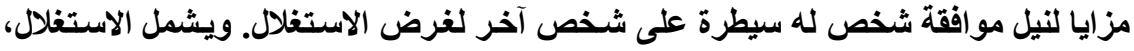

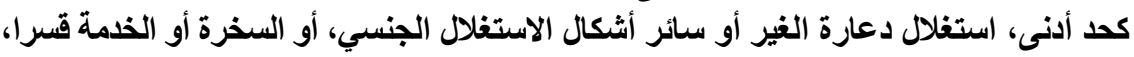

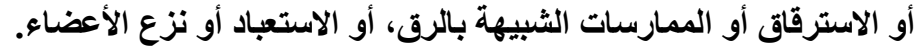

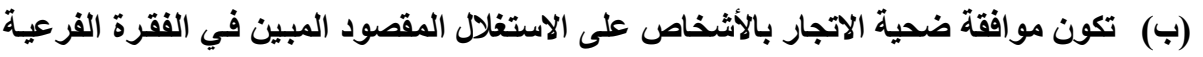

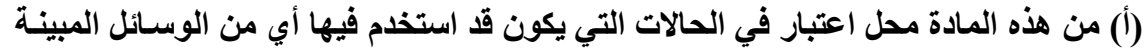
في الفقرة الفرعية (أ).

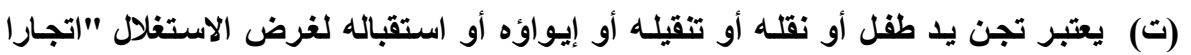

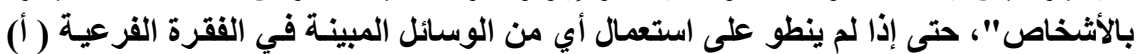


وظيفة ردع وقائية، لأن قانون العقوبات حذر مسبقأ من يريد ارتكاب الجرم عبر وضع لائحة حصرية بهذه الجرائم كي لا يرتكبها الشخص ويحاسب ويُعاقب على ارتكابها، وهذا ما يسمى وظيفة الردع العام لقانون العقوبات. مما لا شكك فيه أن قانون العقوبـات ذات بُعد تعبيري رمزي في كل مُجتمع إذ يعبّر بشكل عام عن مجمل المصالح والقيم الأساسية في المجتمع التي تستوجب الحماية أو بصورة أوضح هو شـاهد على الأهمية التي يوليها القانون لمجموعة من القيّم الأسساسية في المجتمع. هل كل القيّم والمصالح

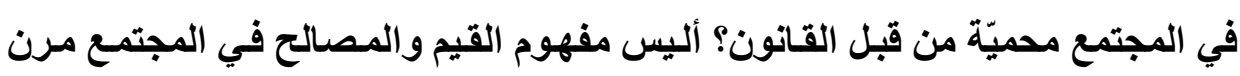
واسع فضفاض؟ ت بـ

حقيقة يجب فهم مصطلح المصالح والقيّم العامة بطريقة غير تقليدية ومرنـة إذ أن هذه المصالح والقيّم تتغير بتغير الزمسان والمكـان أي مـن مجتمع لآخر في نفس الزمسان وفي نفس المجتمـع الواحـد في أزمنـة مُختلفـة. وبالتـالي فـانِ نـوع الحمايـة وأسلوب الحمايـة لذات القيم والمصالح في قـانون العقوبـات تتفــاوت وتتطور متـأثرة بالعديد من العوامل منها:

الفرع الأول :-تطور هفهوم الحماية الجنائية لقانون العقوبات باختلاف الزهمان

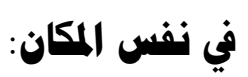
مقارنـة بـين قـانون العقوبـات الفرنسـي القـايم الصـادر سـنة ـ 1 1 ا والقـانون العقوبات الفرنسي الحالي الصادر سنة ؛ 9 ال1 ، القانون ليس بعيداً عن حركة التطور

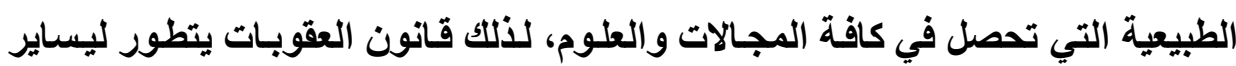
التظورات والتغيرات التي تطرأ على المجتمع الذي يطبق فيه هذا القانون ونصوصه على أفعال أفراد هذا المجتمع. المصالح والقيم الأساسية الراسخة في المجتمع والتي يحميها قانون العقوبات منذ فترة زمنية طويلة تستوجب أن نرصد ونلاحظ عامل مهم 
يتطلق بطريقة وكيفية حمايتها جنائباً عبر نص القانون، بحيث يبدو جلياً أن حماية هذه المصالح تختلف بتغير الزمان في المجتمع الواحد على سبيل المثثال يمكن مقارنة قانون

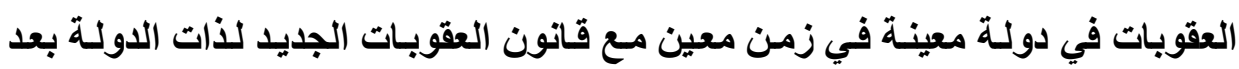

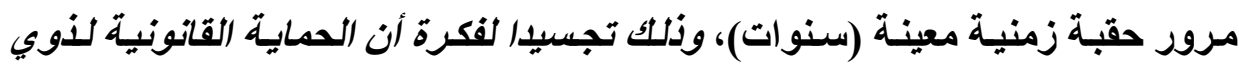
الإحياجات الذاصة تكون بنع استغلال ما لليهم من عوز وعجز جسدي ونفسي وذلك الكي من خلال وضع تشريعات منع الإتجار بالبشر.

ومن الأمثلة المعبرة عن هذا التطور في الحماية الجنائية لقانون العقوبات يمكن الاسترشاد بقانون العقوبات الفرنسي القديم المعروف بـ قانون نـابوليون • 1 1 الألائع

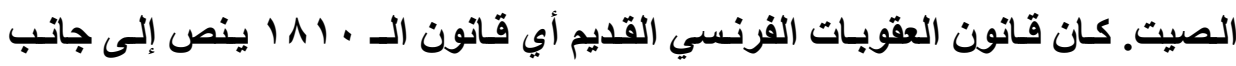

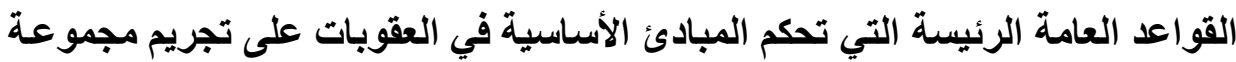
من الأفعال وقد اختار المشرع الفرنسي حينها تبويبها تحت عناوين رئيسة، وهنا نتكلم

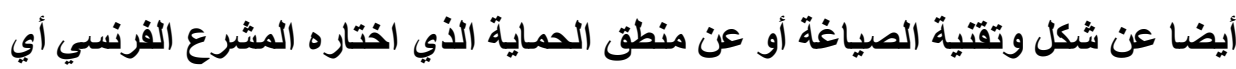
اختيار خطة الحماية الجنائية أثناء صياغة قانون العقوبات. فنلاحظ أن قانون العقوبـات الفرنسي لسنة ـ111 اختـار الخطة التاليـة: جرّم

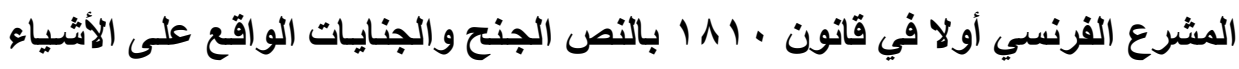

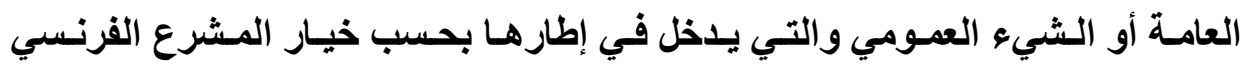

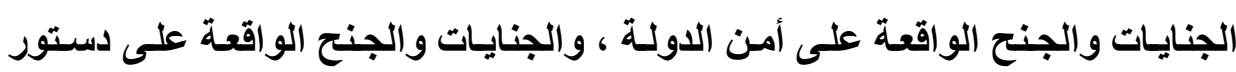

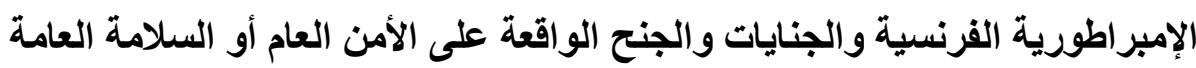
ومن ثم انتقل المشرع القرنسي في قانون العقوبـات لسنة ـ 11 1 إلى عنوان

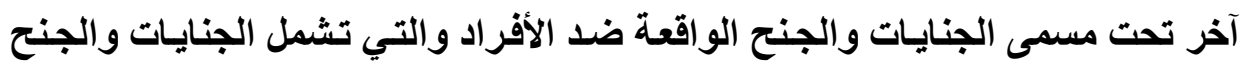

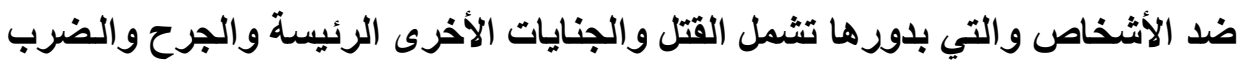


العمدي الغير مؤدي للقتل وجنايـات وجنح أخرى عمديـه بالإضـافة إلى جرائم القتل، الجرح والضرب الخطأ وتشمل الجنايـات والجنح ضد الأفراد بحسب قانون العقوبـات الفرنسي لسنة ـ 1 1 ا الجنايـات والجنح المرتكبة ضد الملكيـة والتي بـورها تشمل جرائم السرقة و الإفلاس والاحتيالوحالات أخرى من النصب أو الاحتيال أما قانون العقوبات الفرنسي الحسالي المعروف تحت مُسمّى قانون ؛ 99 1 فقدا جـاء مُختلفـا في صياغته لشكل وأسـلوب الحمايـة الجنائيـة للمـصالح والقيّم الرئيسة والأساسية في المجتمع الفرنسي إذ غير منطق الحمايـة الجنائية إثـاء صياغة قانون العقوبات على النحو التالي: قسم أسـاس تحت عنوان الجنايـات والجنح المرتكبة ضد الأثخاص الذي يحتوي على الجرائم ضد الإنسانية والاعتداعات الواقعة على الشخص الإنساني كالقتل الإرادي ، ومن ثم ينتقل المشرع الفرنسي في قانون العقوبـات الحسالي (قانون \& 9 9 1) إلى باب آخر تحت مُسمّى الجنايات والجنح ضد الأمسوال التي تحتوي

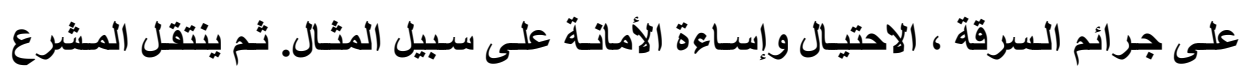

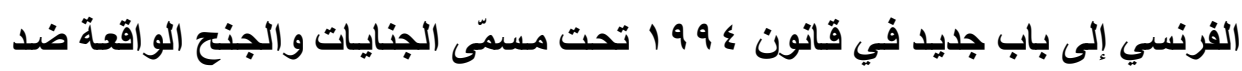
الأمـة، الدولة والسلامة العامـة والتي تشمل جرائم الخيانة، التجسس والإرهـاب على التى سبيل المثال

يتضح من المقارنة التي أجريناها بين خطة وسياسة المُشرّع الفرنسي في صياغة

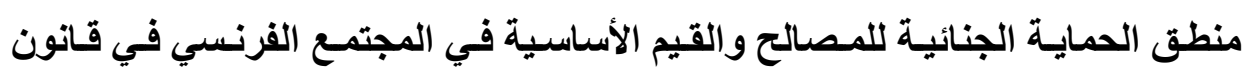
العقوبـات لسنة ـ 1 1 | وبين المنطق والخطة التي استعملها المُشرّع في سنّ قانون

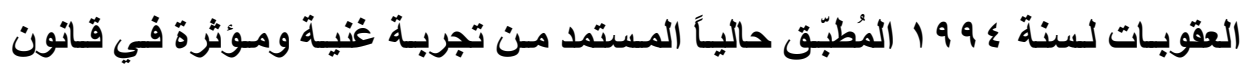
العقوبات الفرنسي، أنه حتى لو كاتت هذه المصالح العليا والقيم المشار إليها سـابقاً محمية في قانون العقوبات منذ فترة زمنية طويلة وراسخة هذه الحماية للقيم في نفس المجتمع ووجدانه، إلا أن مرور فترة زمنية طويلة كافِ بحد ذاتهـ ضمن نفس المجتمع فيله 
على إجبار المشرّع أن يتعامل بذهنية جديدة إثناء صياغة القانون الجديد عن طريق تغيير شكل ووسيلة الحماية الجنائية لهذه المصالح والقيم أو استحداث حماية جنائية لمصالح وقيم جديدة لم تكن مطروحة في القانون القديم عن طريق إضافة نصوص تجريم جديدة أو على العكس إلغاء الحماية الجنائية عن مصالح وقيم لم تعد بذات الأهمية في المجتمع

$$
\text { مع مرور السنوات وتظور المجتمع. }
$$

الفرع الثـاني :-تطـور هفهـوم الصمايسة الجنـائيسة لقـانون العقوبـات في نفسل

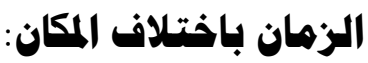

يبدو واضحاً تطور مفهوم الحمايـة الجنائية للمصالح والقيّم بين مجتمع وآخر في نفس الزمـان، أي تطور واختلاف مفهوم الحمايـة في نفس الفترة الزمنيـة داخل مجتمعين مُختلفين، وقد أخذنا على سبيل المثال المقارنة بين قـانون العقوبـات الفرنسي الحالي مـع قانون العقوبـات اللبنـاني الحـالي. إذا هنـاكك أيضا تطور في مفهوم الحمايـة الجنائية للمصالح والقيم الأساسية في قانون العقوبات بتغير المكان، أي ضمن مكانين أو مجتمعين مختلفين في فترة زمنية واحدة. لفهم هذه الظـاهرة كـان من الضروري الاسترشاد بأمثلة عديدة لكن الأكثر تعبيراً عن هذه الظاهرة هو تجريم قانون العقوبـات الفرنسي لمسا يُعرف بـ جريمـة الـ هـابي سـلابينغ Happy Slapping وهي جريمـة مستحدثة أي جريمـة جديدة في قانون العقوبـات الفرنسي أنشأت بموجب قـانون رقم

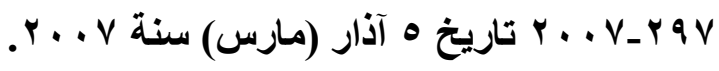
ولكن ما هو مفهوم الـ هابي سلابينغ Happy Slapping هو تصوير الاعتداء الجسدي على حين غرة (المفـاجئ) الواقع على الإنسان بهدف نشرها على مواقع الإنترنت أو تبادلها على الهاتف المحمول بواسطة الرسائل. 
ويُعاقب قانون العقوبـات الفرنسي الشخص الذي قام بالتصوير في جريمة الـ هابي سلابينغ Happy Slapping بنفس العقوبـات التي يتم تطبيقها على الشخص

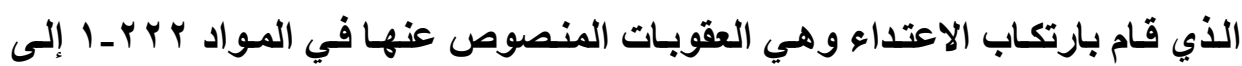

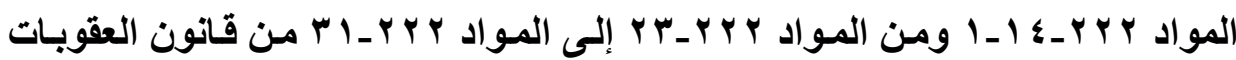
الفرنسي. أمسا سـبب تطبيق نفس العقوبـة على الشخص الذي قـام بتصوير الاعتداء Complicité الجسدي فهو باعتبار أن فعل تصوير الاعتداء يُعتبر اشتراك جرئي

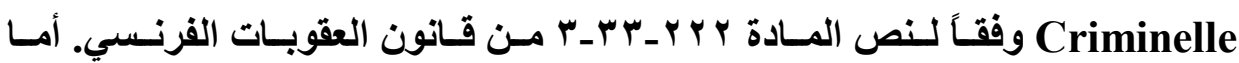
مسئولية نشر مقطع فيديو الاعتداء فتصل عقوبتها في القانون الفرنسي للحبس ه

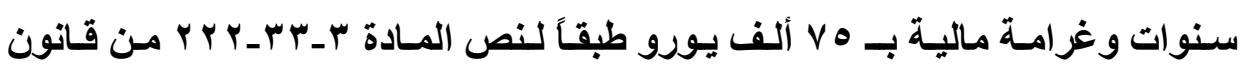
العقوبات الفرنسي.

يتضح إنتا أمام حماية من نوع خاص أقل عمومية وعالمية على صعيد الانتشار

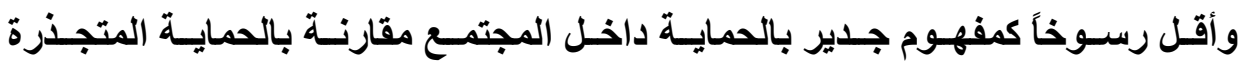
والمتأصلة والراسخة لجريمـة القتل على سبيل المثال. القـانون عامـة وتحديدا بشكل خاص قانون العقوبات يعبر عن خيار Choix لسياسة معينة ينتهجها المشرع في كل دولة في اختيار سياسة مُعينة في التجريم أو الإباحة مما يعكس توجه مُعيّن في اختيار أو تقرير شكل حماية المصالح والقيّم العُليا في المُجتمع وهي تختلف بين مُشرّع وآخر باختلاف المُجتمع.

وهذا ما يظهر لنا واضحا في تجريم الـ هابي سـلابينغ Happy Slapping في قانون العقوبـات الفرنسي في نفس الوقت الذي تغزو فيه ظـاهرة الـ هـابي سـلابينغ المجتمع العربي بكل بشاعتها دون أن تشكل أي نفور أو استياء في المُجتمع العربي،

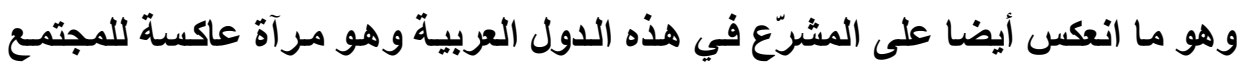
يشرّع بتفويض منهاو وعلى صورتها، وبالتالي لم يُفكر المشرّع اللبناني أو غيره في 
الدولة العربية من تجريم هذه الظاهرة السيئة المنتشرة بكثافة على مواقع الإنترنت العربيـة وبين الأفراد الذين يتبـادلون هذه الفيديوهات فيمسا بيذهم بواسطة الرســائل

ما سبق يفتح المجال عن الحديث عن العلاقة التي تجمع بين قانون العقوبـات وبين القواعد السلوكية والأخلاقية التي تؤثر وترشـد حتمـاً في سياسية واختيـارات

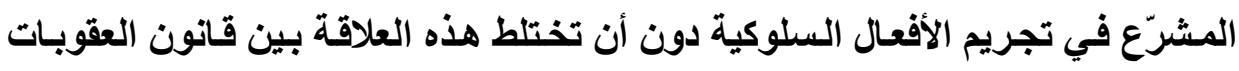
والقواعد السلوكية والأخلاقية داخل كل مجتمع.

في المبدأ قانون العقوبات لا يُعاقب كل انتهاك لقاعدة سلوكية أو أخلاقية اتفق

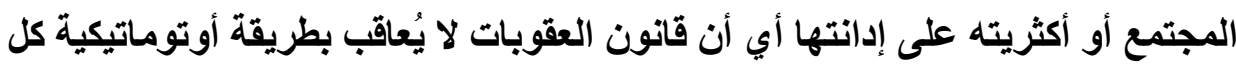
التصرفات أو الاتتهاكات المرفوضـة و المنبوذة من قبل المجتمع ولكنه دون شكك يتأثر

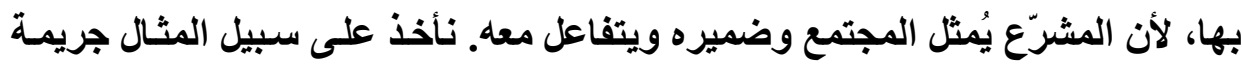

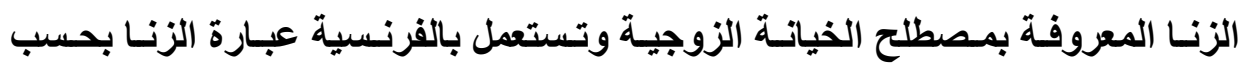

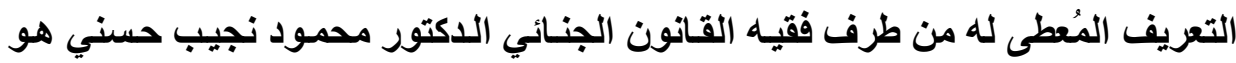

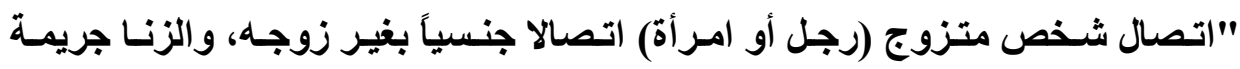

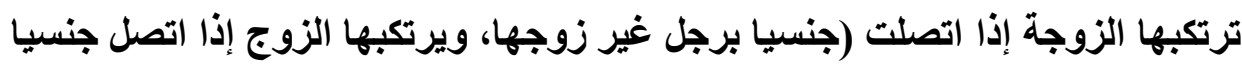
بامر أة غير زوجته" فجريمة الزنا هي العلاقة الجنسية التي يقيمها إحدى طرفي عقد الزواج مع شخص من خارج هذه الرابطة الزوجية أو إطار الزواج:

القانون الفرنسي القديم كان يُعاقب الزوجة المُرتكبة لجريمة الزنـا بعقوبة اثدّ

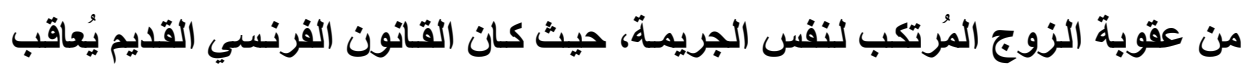

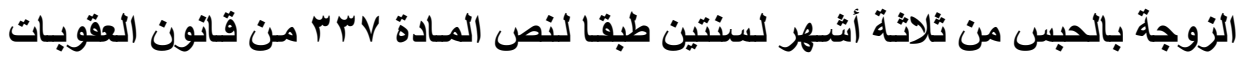

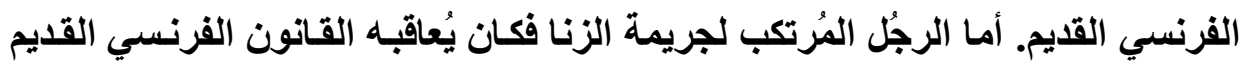




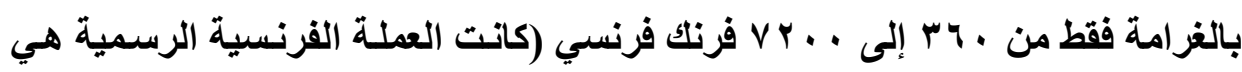
الفرنك الفرنسي حينها) وفقط في حالة إقامة العلاقة الجنسية في المنزل الزوجي. طرأت لاحقًاً تطـورات وتغيـرات فـي مفهوم وتقيـيم المجتمـع الفرنسـي لهـذه الجريمة والنظرة إليها دفعت المشرع الفرنسي إلى التجاوب والتفاعل معها وأدت في المحصلة النهائية إلى إخراج جريمة الزنا من مجال التجريم في القانون الفرنسي سنة

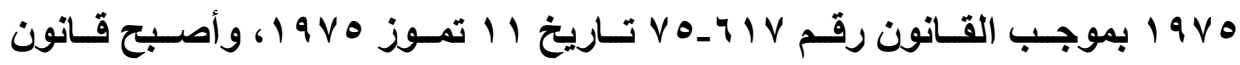
العقوبات الفرنسي لا يُعاقب على ارتكـاب فعل الزنـا، أي لا يُعتبر العلاقة الجنسية لأحد طرفي عقد الزواج مع طرف ثالث جريمـة في نظر قانون العقوبـات الفرنسي من ذلك

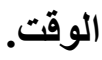

وممـا لاشكـ في أن القـانون هو مر آة تعكس عـادات وتقاليد وصفات ومفـاهيم المجتمـع في كل دولة، ويبدو جلياً نتـائج تأثر المُشرع في كل دولة بهذه التأثيرات

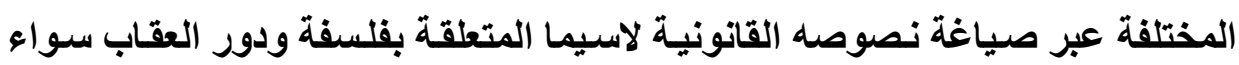

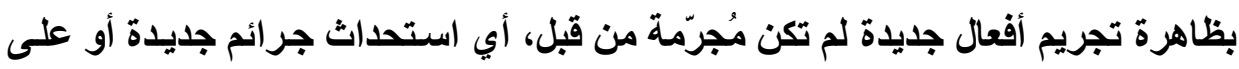
النقيض مـن ذلك عن طريق إلغـاء بعض الجرائم التـي اعتبرهـا المجتمـع (بأكثريتهـ) بمـرور الزمن غير ذي أهميـة أو غيـر جديرة بالحمايـة الجنائيـة وبالتـالي إخراجها المُشرّع من دائرة التجريم.

في المقابل المجتمع العربي لم يغير نظرتهـه وموقفهـ من العلاقة الجنسية خـارج نطاق أو إطار عقد الزواج، وبالتالي فإن جريمة الزنا بقيت محل تجريم في التشريعات الجزائية العربية. على سبيل المثال فـإن قـانون العقوبـات اللبنـاني يُعـالج موضوع الزئا في إطـار الجنح المخلة بـآداب العيلية، بحيث يُعاقب المرأة إذا ارتكبت جريمـة الزنـا بعقوبة الحبس من ب أشهر كد أدني وتصل العقوبة لحد أقصى هو ثلاثتة سنوات طبقاً 


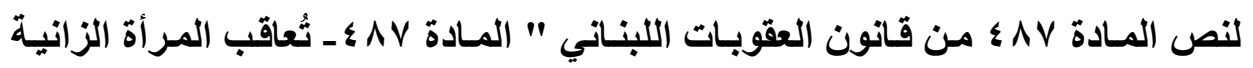
بالحبس من ثلاثة أشهر إلى سنتين.

ويقضى بالعقوبة نفسها على شريك الزانية إذا كـان متزوجـاً وإلا فبـالحبس من شهر إلى سنة، أما عقوبة الرجل الذي يرتكب جريمة الزنا في قانون العقوبـات اللبنـاني فتتراوح بين الحبس من شهر إلى سنة إذا ارتكب جُرم الزنـا في البيت الزوجي أو إذا اتخذ له خليلة جهاراً (بشكل علني مفضوح) في أي مكان حسب تعبير المشرّع اللبناني،

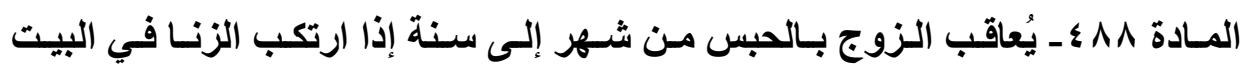
الزوجي أو اتخـذ لـه خليلـة جهاراً في أي مكسان كـان. وتنزل العقوبـة نفسها بـالمرأة الثريك". وعلى الهامش يمكن مُلاحظة التمييز في مقدار العقوبة من جهة بين الرجل الزاني والمرأة الزانية في قانون العقوبات اللبناني ومن جهة أخرى في أركـان جريمـة الزنا المرتكبة بين الرجل الزاني والمرأة الزانية.

وفي الحالتين نلاحظ أنهه تمييز غير عـادل يجعل المشرع اللبنـاني مُخلاً بشكل سـاطع وفاضـح في المساواة بيل الرجل والمرأة في مجـال تجريم الأفعال المتشابهة سلوكيا وأخلاقيا في الوقت الذي أصبحت فيه جريمة الزنا فُهددة بالانقراض من وجدان الجماعة والمجتمع في العديد من الدول الأوروبية بعد أن أخرجها المشرّع في العديد من هذه الدول من نطاق الجريمة كلياً.

لذلك فتأثير تغيّر وتطور المصالح والقيّم الاجتماعية على قانون العقوبـات العام والخـاص: لا يخضع لقانون العقوبـات العـام كون هذا التطور والتغيّر السريع إجمالا. وعلـى العكس مـن ذلــك يُعتبـر قـانون العقوبـات الخـاص بمثابـة أرض خصبة لهـذه التطورات. في هذا المجال يوجد حركتين أو عمليتين تسيران بعكس بعضهما البعض أو حركة مزدوجة مؤلفة من تجريم وعدم تجريم. الأولى: حركة تسير نحو توسيع نطاق تهي 
التجريم من قبل المشرّع في قانون العقوبـات وثُعرف هذه الحركة أو الظاهرة: حركة

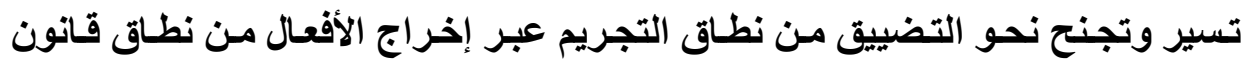

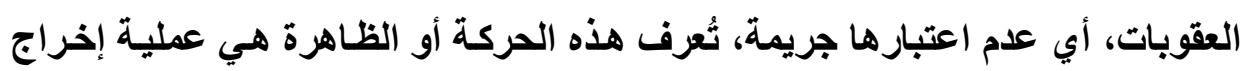
الفعل من نطاق التجريم أي اعتباره لا يشكل جريمة عبر إلغاء نص القانون الذي كان التهان

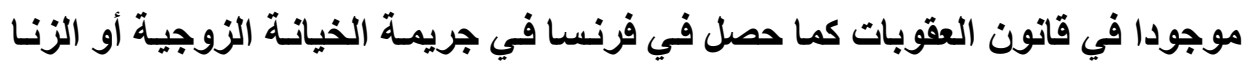

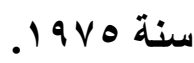

إن توسيع نطاق العقاب والتجريم يرمز أن إرادة المشرّع تذهب باتجاه إضافة

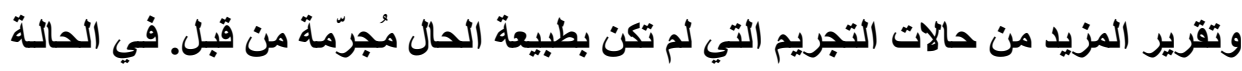

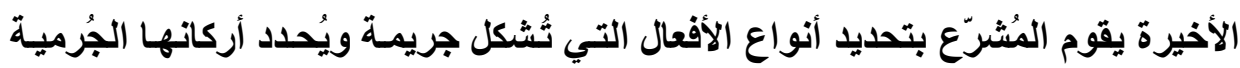

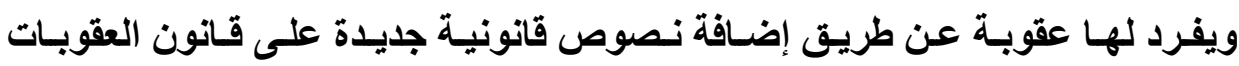

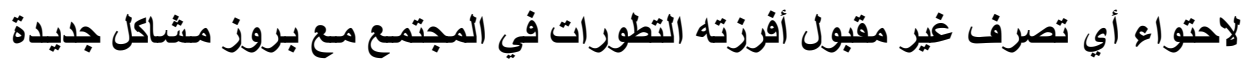

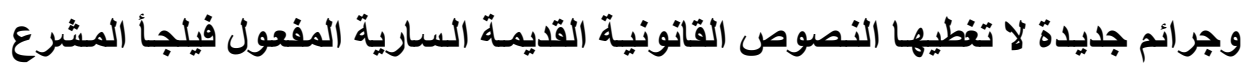
لتجريم هذه الأفعال بنصوص قانونية جديدة لاحتواء هذه الأفعال وإسباغ حماية جنائية

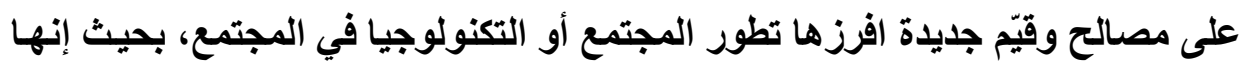

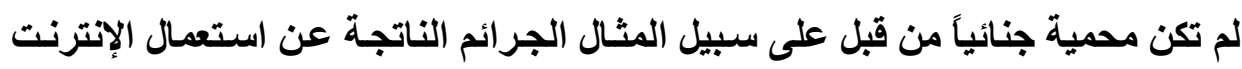
وتفرعاتها أو الجرائم الإرهابية.

وعلى سبيل المثـال في تـأثر الحمايـة الجنائيسة التـي يُقررهـا المشرع بتطور

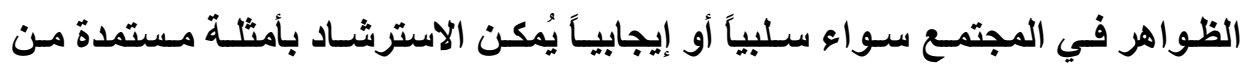
القـانون الفرنسي إذ كـان قـانون العقوبـات الفرنسي القـديم و المعروف باسـم قـانون

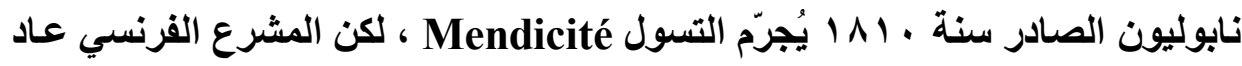

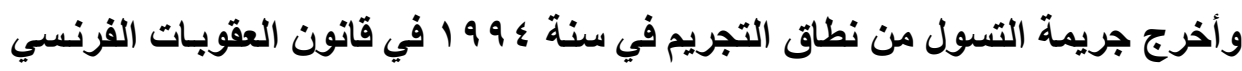


ولكن مـا لبس المُشرّع الفرنسي أن عاد مرة أخرى وادخل التسوّل في نطاق

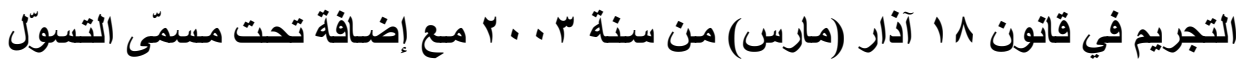
هي عبارة التسول تحت ضغط أو عدوانية أو بواسطة التهديد بالحيوانـات الخطرة طبقا

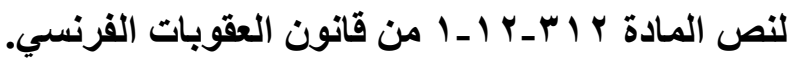
هنـاك تغيّر وتبـل في مفـاهيم المجتمـع هـي التي أدت أو دفعت سـابقاً المشرّع الفرنسي لتجريم فعل أو سلوك معين من ثم أجبرتـه على إلغائهه من نصوص قـانون العقوبات ومن جديد أدت إلى دفعه إلى إعادة تجريمـه مجددا مـع إضـافة مُتمثلة بأركان الجريمة مُستمد من تسميتها وبناءهـا النصي أي صياغة نص التجريم كمـا أسلقنا في جريمة التسوّل في قانون العقوبات الفرنسي.

وتبدو العلاقة واضحة بين الضرر الأي يَّهد المجتمع وبين سنّ القوانين التي تمنع القيام بالأفعال الضارة في المجتمع، وتتجسد هذه العلاقة في نص المـادة الخامسة من الإعلان الفرنسي لحقوق الإنسان والمواطن الصادر عـام IVA9 على مـا يلـي: "ليس للقانون الحق في منع سوى الأعمال الضارة بالمجتمع. فكل ما لا يحرمه القانون

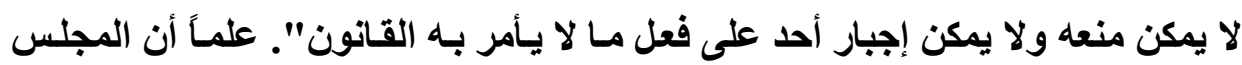

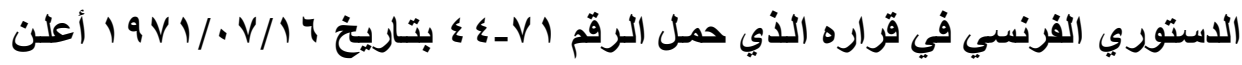

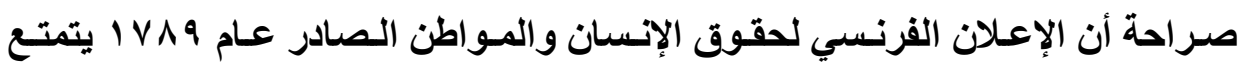
بقيمة قانونية دستورية في القانون الفرنسي وبالتالي يتربع على قمـة البنـاء القانوني، في هرم القواعد القانونيـة طبقاً لفكرة تـدرج القواعد القانونيـة التـي ابتـدعها الفقيـه القانوني النمساوي هانز كيلسّن . 


\section{الخاتهة}

على ضوع ما تقدم فإن هذه الدراسة توصلت للنتائج والتوصيات الأتية:-

$$
\text { أولا: - النتائج :- }
$$

1ـ أن لذوي الاحتياجات الخاصة حقوقاً نصت عليها القوانين والمواثيق الدولية. r ـ أن مكافحة جرائم الاتجار بالبشر منصوص عليها بقانون منـع الاتجـار بالبشر لعام 9 ، . . r وهو متسقاً مع القوانين الدولية. r- ت تثوفر الحماية القانونية لذوي الاحتياجـات الخاصـة من الاتجـار بهم حسب مـا نص عليه القانون. ع- أن ظاهرة المتاجرة بالبشر ـ ظاهرة ضـاربة الجذور في التاريخ وممـا يؤكد وجودها حتى قبل نزول الشرائع السماوية كافة بلدليل معالجة تلكك الثرائع لها، إلا أن صورها كانت تختلف من مرحلة لأخرى وحسب اختلاف الحقبة الزمنية. هـ أن الإنسان هو المحور الأساس لهذه الظاهرة الخطرة فبدون الإنسان لا يمكن لهذه الظاهرة أن تتم فالإنسان هو الضحية التي تتم بها تلك الظاهرة. ا- لظاهرة الاتجار بالبشر أشكال مختلفة حيث ترد هذه الظاهرة تارة على إجبار الإنسان على القيام بأعمال تثكل انتقاصا لحريته وآدميته وكرامته الإنسانية بالأعمال الثاقة والتي قد تكون في مواقع خطرة وبأجور زهيدة، كمـا قد ترد

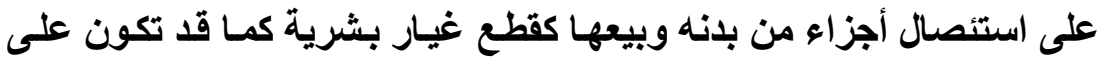
شكل إجبار الضحايا على القيام بأعمال منافية للشرع والقانون ومنها الأعمال 
الجنسية أو السرقة أو المتاجرة بالمواد الممنوعة واستغلال ما لديهم من عوز

$$
\text { وعجز جسدي ونفسي وغيرها }
$$

V- تمتاز هذه الظاهرة بكونها ظاهره معقده، ومن ذلك مثثلا أن إحدى الدول لو حاولت التصدي لهذه الظاهرة وطوقت أسباب نشوؤها وعالجت آثار هـا لظلت هذه الدولة على الأقل كدولة مرور (ومع ذلك فهو افتراض صعب التحقق). 1- تتوزع أسباب نشوء هذه الظاهرة إلى أسباب عامـة وأخرى خاصـة وعمومـا نجد أن من أهمها الأسباب الاقتصادية وتأتي في مقدمتها الفقر والطبقية وانعدام التوازن الاقتصادي بين فئات المجتمع، كمسا أن منها أسباب ديموغرافية كانعدام التوازن بين عدد الذكور والإنـاث وعدم وجود قاعدة تثريعيه محكمة وضعف الوسائل الرقابية والكوارث الطبيعية وغيرها. 9 ــ أنها ظاهرة صارت تمتاز أيضا بكونها صـارت عابرة للحدود(عبر الوطنية) حيث لم تعد هذه الظاهرة قاصرة على ذات الدولة الواحدة بل صارت تتبع في دولة وتمتد آثارها إلى دولة أخرى وعليه ظهرت ما تسمى بدول المنبع ودول

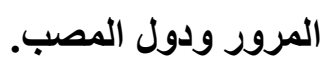
• 1 - إن الحماية القانونية لذوي الإحياجات الخاصة تكون بمنع استغلال ما للديهم من عوز وعجز جسدي ونفسي وذلك من خلال وضـع تشريعات منـع الإتجار بالبشر.

\section{ثانيا:- التوصيات:}

ا - إصدار قانون خـاص بمكافحة الاتجار بالبشر في كافة الدول، التي لـ تسنه لغاية تاريخه؛ وذلك لعدم كفايـة القوانين التقليدية السارية المفعول لمواكبة بانة الأساليب الحديثة في مجال الاتجار بالبشر؛ كذلك أيضا مراجعة التشريعات المكملة لتشريعات مكافحة الاتجـار بالأشخاص، خاصـة تشريعات العمل، 
مكافحة العنف ضد المرأة، حمايـة الطفل، العمل والعمـال، الإقامـة والعمالة الأجنبية والكفالة،... وغيرها من التشريعات التي تتعلق بحقوق الإنسان. r- تكثيف برامج التأهيل والتدريب المستمر، لبناء القدرات وتنميتها لاى القائمين على أجهزة تنفيذ القانون من رؤسساء ومروؤسين في الأجهزة القضائية والأمنية الموظفين والمسئولين الحكوميين على تقنيات مكافحة الاتجار بالبشر البر وأسـاليبها، للاحتراف في ملاحقة هذه الجرائم والتحقيق فيها ومحاكمة الفاعلين وذلك تجسيدا لفكرة أن الحمايـة القانونية لذوي الإحياجات الخاصـة تكون بنـع استغلال ما لليهم من عوز وعجز جسدي ونفسي وذلك من خلال وضع تشربعات منع الإتجار بالبشر. r- التأكيا على أهمية دور رجـال الأمن العـام في كسب ثقة الرأي العـام لا سيما الضحايا لإبلاغها عن مختلف أنواع الجرائم وتعزيز تعـاون النـاس مـع أجهزة إنفاذ القانون. عـ ملاحقة المتاجرين ومقاضاتهم بكل أوجه المشاركة الجرميـة بعقوبـات صسارمة مانعة للحرية. هـ مكافحة الفساد الذي يسهّل ويروّج للاتجار بالبشر لا سيما العابر للحدود، عبر سن تشريعات خاصـة، ووضـع اتفاقية الأمـم المتحدة لمكافحة الفساد قيد التنفيذ. צ- حماية الضحايا، والثهود نظرا إلى ما تتوافر لايهم معلومات من شـأنها جمع الأدلة وتعقب المجرمين والأهم تقديم المساعدة الماديـة والمعنويـة لهم ملهم ولأسر هم، ومعاملتهم كمجني عليهم وليس كجناة. 
V- رصد وملاحقة الأموال والأربـاح الهائلة الناتجة عن هذا الاتجـار، ومنع تبييضها بشكل من الأشكال، وتجميد هذه الأموال في صندوق استئماني لتعويض المجني عليهم.

1- توفير الإمكانيات المالية والمادية لدعم جهود الجهات ذات الاختصاص الهادفة إلى تنفيذ برامج الوقاية من جرائم الاتجار بالبشر ومنعها ومكافحتها. 9- تفعيل عمل اللجان الوطنية متخصصة بمكافحة الاتجـار بالبشر، التي شكلت بالتنسيق مـع الجهات ذات الاختصاص في كل دولة عربية، وبالتعاون مـع المؤسسات الأمنية، والمؤسسات الاينية، وذلتك لإعداد دليل إرشسادي للأشخاص المحتمل وقوعهم ضحايا، وأيضا لإعداد تقارير سنوية وإصدارها، فضلا عن التنسيق على المستوى الوطني، الإقليمي والدولي بين الخطط والبرامج للتصدي لظاهرة الاتجار بالبشر. • 1 ـ تفعيل دور مؤسسات المجتمع المدني بمـا في ذلك المؤسسات الأكاديمية والمؤسسات الدينية والمنظماتـ غير الحكومية ووسائل الإعلام، في التوعية بمخاطر الاتجار بالبشر وسبل الوقاية منه، أيضا في التثقيف والتنمية الفكرية والبشرية لمكافحة الجهل وضعف الوعي بالحقوق الإنسانية. 11 اـ التأكيد على المسئولية المجتمعية للشركات كوسيلة من وسـائل مكافحة الاتجار بالبشر بقصد العمل، وخاصة فيما يتعلق بتحريم عمالة الأطفال والعمل القسري والعمل الإجباري. r ا ـ دعوة الدول العربية التي لم تصدق لغاية تاريخه على البروتوكول الأول لمنع الاتجار بالبشر وقمعه ومعاقبته، وخاصة النساء والأطفـال الملحق باتفاقية الأية الأمم المتحدة لعام | | | ب بشأن مكافحة الجريمة المنظمة العبر وطنية وسائر الصكوك الاولية الأخرى ذات الصلة. 
ب ا - بالنظر إلى أن جرائم الاتجار بالبشر تعد من صور الجريمة المنظمة العابرة

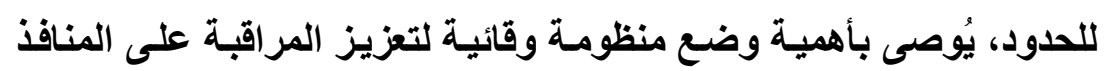

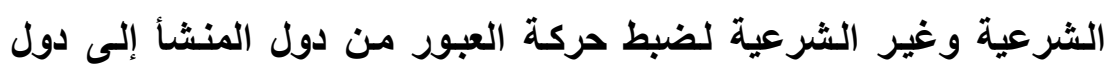
المقصد.

؛ اـ التعاون بين الأجززة القضائية والمؤسسات الأمنية وسائر الجهات المختصة،

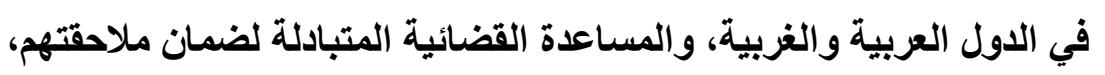
تسليمهز، جمع الأدلة الكافية للكثف عن الحقيقة. 10ـ ضرورة تبادل الخبرات بين الدول العربية والاستعانة بالخبرات الأجنبية

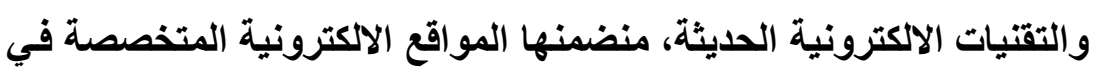
مجال التصدي لجرائم الاتجار بالبشر. 17 ا وضع تدابير تكفل عدم وصول القياديين في عصابات الاتجار بالبشر إلى إلى

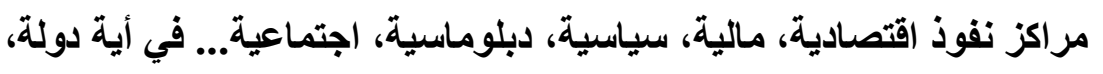

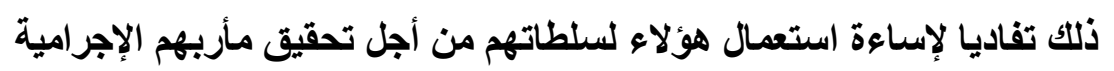
من تمرير الصفقات المشبوهة، والتهرب الضريبي، وعمليات غسل الأموال وتحقيق المكاسب غير المشروعة.

V ا ـ دعم المحاولات الجادة والجارية حاليا لتشكيل لجنة عليا، وضع استراتيجيات وخطط مكافحة الاتجار بالبشر على المستويين العربي والإسلامي.

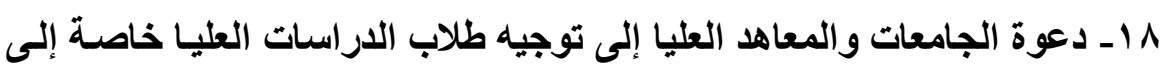

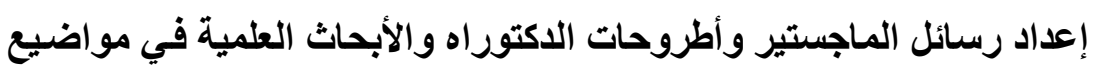
لها صلة بالاتجار بالبشر ، وإدراجها ضمن البرنامج التعليمي. 9 اـ تكثيف تنظيم وعقد المؤتمرات والندوات العلمية المحلية، الإقليمية والدولية،

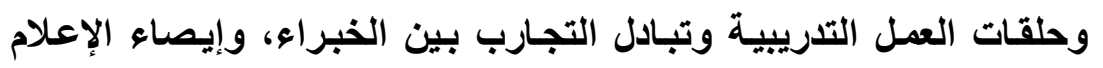


لمواكبة هذه النشاطات وإيلاءهـا أهمية أساسية لتوعية الرأي العـام العربي

$$
\text { والعالمي. }
$$

• • ـ تـوفير التـدريب الكـافي للكـادر المهنـي مـع الاهتمـام بتوفير وسـائل مسـاعدة للتغلب على المشاكل التي تواجه الطلبة ذوي الاحتياجات الخاصة. ابـ تسهيل الإجراعات للتظلب على المصاعب التي تسببها الإعاقة والتي تساعد الطلاب المعاقين في الحصول على بدائل تمكنهم من الاندماج مع المجتمع. r Y ـ اهتمام الإعلام بقضية الامج والتعليم عبر لقاءات خاصة مع ذوي الاختصاص من مشرفين ومعلمين، وأطفـال معاقين لنقل الصورة بشكل صحيح وواضح للمواطن العادي، كما يساعد على تعديل الاتجاهات المعادية للفكرة. ب ـ الاهتمام بتوفير فرص الدمج لجميع فئات ذوي الاحتياجات الخاصة بعد توفير الإمكانات المادية والبشرية لتعليمهر. צ ؟ ـ دعم أسر ذوي الاحتياجات الخاصة لتستطيع أن ترعى الطقل ذوي الاحتياجات الخاصة بدلا من إلحاقهم بالمدارس الداخلية ليتخلصوا من نفقاتهم. ه بـ على أسر ذوي الاحتياجات دمجهم اجتماعيا في المجتمع المحيط بهم قبل أن تفكر في دمهم اجتماعيا، وعليهم أن يـركوا أن الطفل ذوي الاحتياجـات ليس اليس طقل مختلف بل طقل طبيعي لايه بعض الاحتياجات أكثر من أقرانه. 


\section{المراجع}

\section{أولا: المراجع العربية:}

1 ـ أحمد الزعبي: الأمراض النفية والمشكلات السلوكية والدراسية عند الأطفال، دار

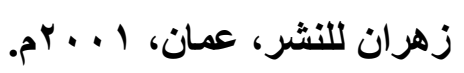

r ـ أحمد خطابي، الواقع الاجتمـاعي وحقوق ذوي الاحتياجـات الخاصـة في المجتمع

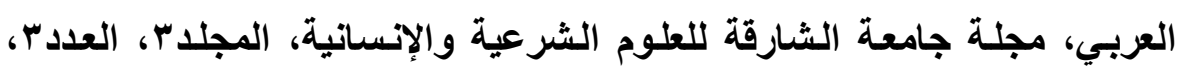

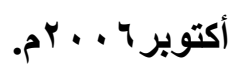

r- إسماعيل محمد حنفي: دور الدولة في رعاية ذوي الاحتياجات الخاصة في الإسلام،

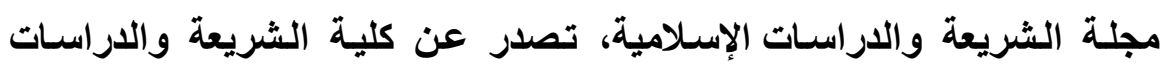

$$
\text { الإسلامية بجامعة إفريقيا العالمية (العدد الأول). }
$$

$$
\text { ع - منشورات مركز عدالة، النسخة الإكترونية، عمان - الأردن، V . . Y. }
$$

هـ إيهـاب البـبلاوي: توعيـة المجتمـع بالإعاقـة، مكتبـة الرشــ، الريـاض، (د. ت)،

$$
\text { م. . . ع }
$$

צ- باسم المفضي المعايطة: عيوب النطق وأمراض الكلام، رسـالة الماجستير، جامعة

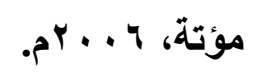

V- بطرس حافظ بطرس: صعوبات التعلم، القاهرة، حورس للطباعة والنشر، 999 ام. ^ـ تهاني محمد عثمان منيب: أولياء ذوي الاحتياجات الخاصة وسبل إرشادهم، جامعة

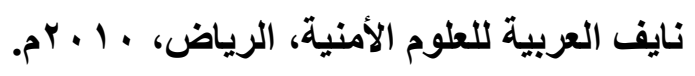

9- تهاني محمد عثمان: أولياء ذوي الاحتياجات الخاصة وسبل إرشادهم، جامعة نـايف

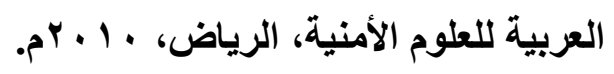


ـ 1 ـ جمال محمد الخطيب: تأثيرات الدمج على القبول الاجتماعي للأطفال ذوي الحاجات

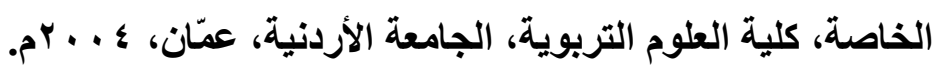

1 ا ـ حامد سيد محمد: الاتجـار في البشر كجريمـة منظمة عابرة للحدود، القومي

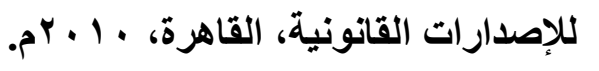

r ا ـ حامد عبد السلام زهران: التوجيه والإرشـاد النفسي، طب، عالم الكتب، القاهرة، .ค) $9 \wedge$.

r ا ـ خالـا عبد الحميد عثــان: مظـاهر الصحة النفسية لذوي الاحتياجـات الخاصـة،

$$
\rho^{r} \cdot v
$$

ـ ا ـ سالم الكسواني: مبادئ القانون الاستوري مـع دراسـة تحليلية للنظام الدستوري

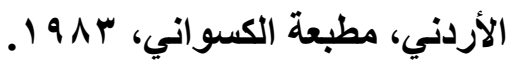

ه 1 ــــر أحمــ الخشرمي: دمـج الأطفــال ذوي الاحتياجـات الخاصـة فـي المــارس

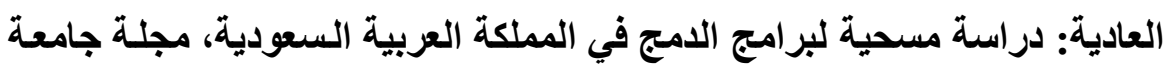

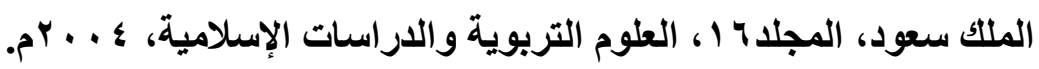
7 ا ـ سهير محمد خيري: رعاية الفئات الخاصة من منظور الخدمة الاجتماعية، جــ،

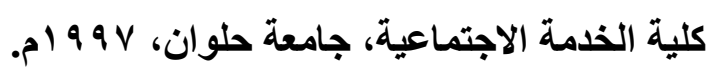
V ا ـ سوزي عدلي ناشد: الاتجار في البشر بين الاقتصاد الخفي والاقتصاد الرسمي،

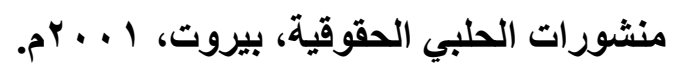

1 اـ السيد أحمد رزق رياض: القضاة تطالب بتفعيل الاتفاقات الدولية لمكافحة الاتجـار بالبشر والهجرة غير الشرعية، بحث منشور على شبكة المعلومـات الدولية

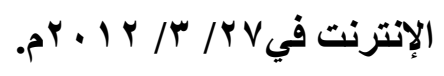


9 ا ـ شبكة مراسلون بعثة الاتحاد الأوربي تقيم دورة في الممارسـات الفضلى لمنـع

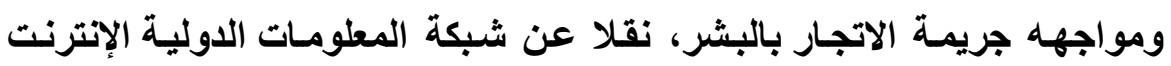

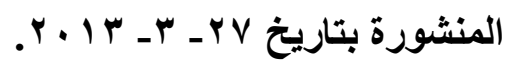

• • ـ الإمام محمد بن أبي بكر بن عبد القادر الرازي، مختار الصحاح، دار الغد الجديدة،

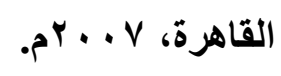

ا ا ـ صموئيل ويثك، كيف تربي طقلك المعوق، ترجمة : د. محمد نسيم رأفت. r Y _ طارق زكي موسى: اضطرابات الكلام عند الطفل، دار العلم والإيمان، كفر الشيخ،

$$
\text { م. ^ }
$$

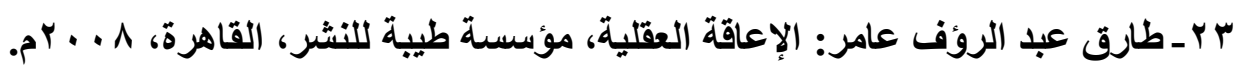
צ r ـ عادل عبد الله محمد: الأطفال التوحدين: دراسات تشخيصية وبرامجية، مكتبـة دار

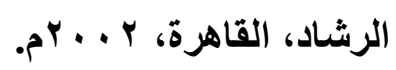

ه ب ـ عادل عبد الله محمد: مقياس جيليام التقديري لتشخيص اضطراب التوحد، مكتبة

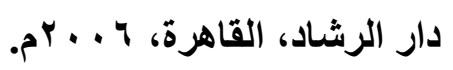

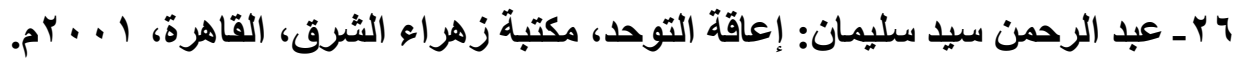
r Y ع عبد الرحمن سيد سليمان: سيكولوجية ذوي الحاجـات الخاصـة، زهراء الشرق،

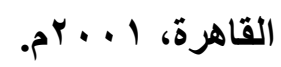

^ץ ـ عبـد العزيـز القوصسي: أسس الـصحة النفسية، دار النهضة العربيـة، القـاهرة،

$$
\text { . }) \text { । } \vee 0
$$

q ץ ـ عبد المطلب القريطي: سـيكولوجية ذوي الحاجـات الخاصـة وتربيتهم، طس، دار

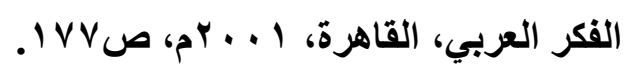


· r ــ عثـان لبيب فراج: "استراتيجيات مستحدثة في برامج رعايـة وتأهيل الأطفال

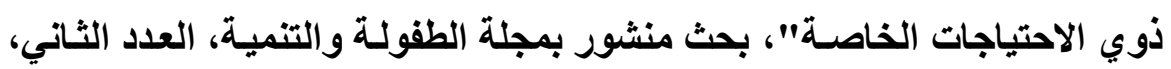

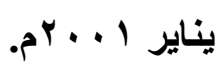

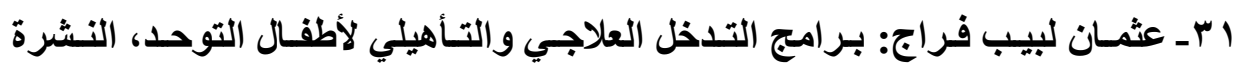

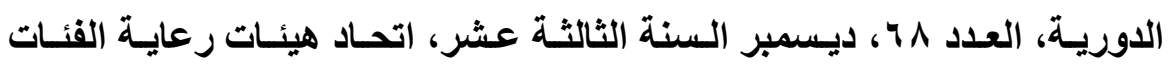

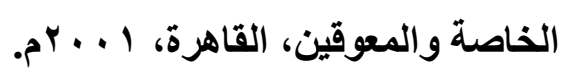

r Y ـ فتحي مصطفي الزيات: صعوبات التعلم: الأسس النظرية والتشخيصية والعلاجية،

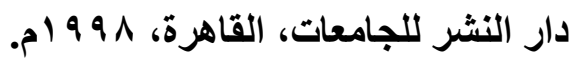

rr بـ فهل بن محمد الحمد: حماية الطقل في نظام مكافحة جرائم الاتجار بالأثخاص،

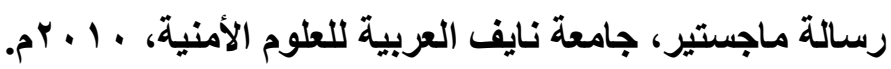

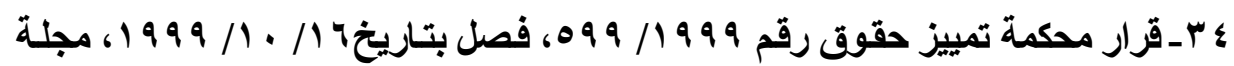

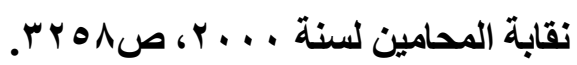
هـ ــ محمد الثنداوي: نظريات الإرشاد والعلاج السلوكي، دار غريب للطباعة والنشر،

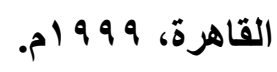

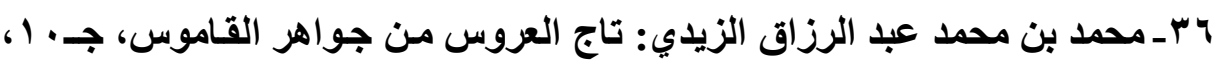
تحقيق مجموعة من المحققين، دار الهاية. VT ـ محمد بن مكرم بن علي أبو الفضل ابن منظور، لسان العرب، جـ ـ ا، بيروت، دار

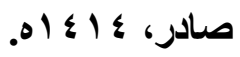

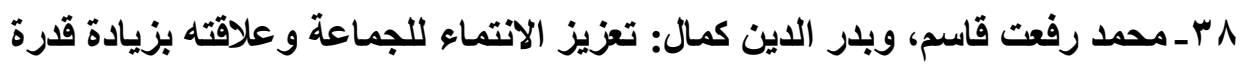

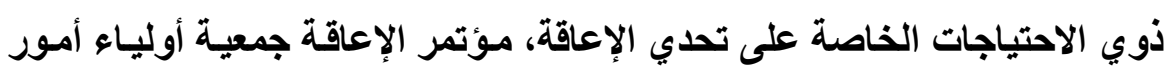

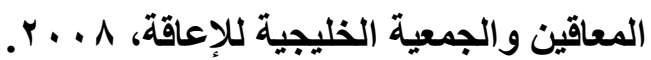


q بـ محمد عبد المنعم نور: الخدمة الاجتماعية الطبية والتأهيل، دار المعرفة، القاهرة،

$$
\text { . }) 9 \wedge 0
$$

• ـ ـ محمد يوسف علوان: القانون الدولي العام، المقدمة و المصادر، دار وائل للنشر،

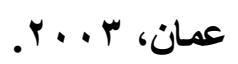

اء ـ غسلن الجندي، الجماليات البركانية في مبادئ القانون الدولي العام، دار وائل،

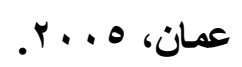

ץ ع ـ صلاح الدين عـامر، مقدمة لاراسـة القانون الدولي العام، دار النهضة العربية،

$$
\text { . } r \text {. r }
$$

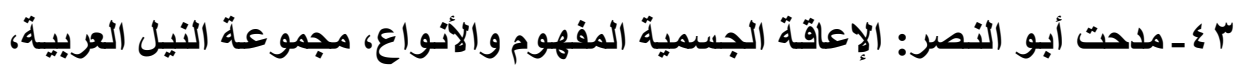

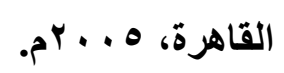

؛ ـ ـ مصطفى نوري القمش: الإعاقة السمعية واضطرابات النطق، دار الفكر، عمـان،

. 1999

ه ـ ـ مـؤتمر "رعايـة الإسـلام لذوي الاحتياجـات الخاصـة" الذي عقد بكليـة الشريعة

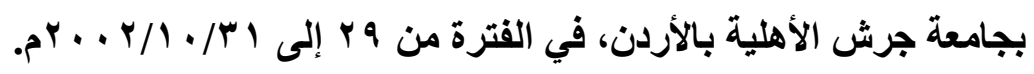

צـ الموسوعة العربية العالمية، مؤسسة أعمـال الموسوعة للنشر والتوزيع،

$$
\text { . } 1997
$$

V \& ـ نادر عبد العزيز شافي: الاتجار بالبشر من أخطر الجرائم بحق الأفراد والمجتمعات

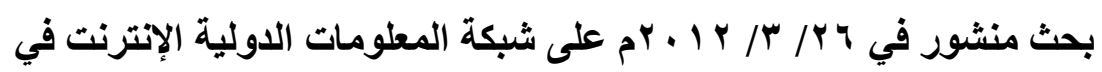

http://www.lebarmy.gov.ib/articale.asp

1 ـ ـ ناريمان محمد رفاعي، محمد عوض الله سالم: دراسة لبعض خصائص الثخصية

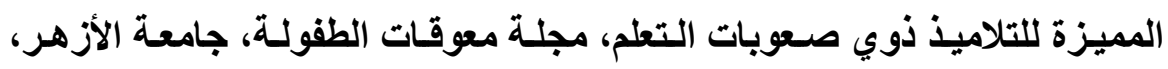
المجلد الثاني، العدد الأول، بـو 99 أم.

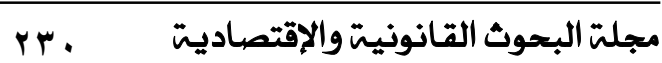


q ـ ـ ناصر راجـح الشهراني: الإطـار التشريعي لمكافــة الاتجـار بالبشر في المملكـة

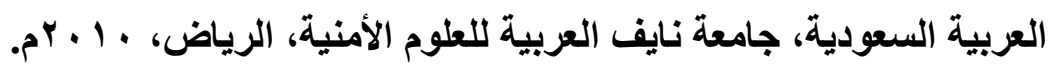

• هـ هادي نعمان الهيتي: بحث بعنوان: "الاتصال الجماهيري حول ظاهرة الإعاقة بين

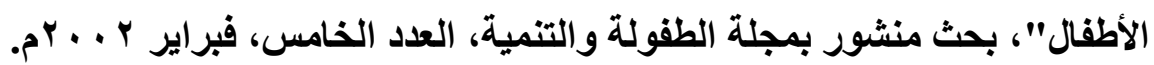
1هـ هادي نعمان الهيتي، الاتصال الجماهيري حول ظاهرة الإعاقة بين الأطفال، مجلة

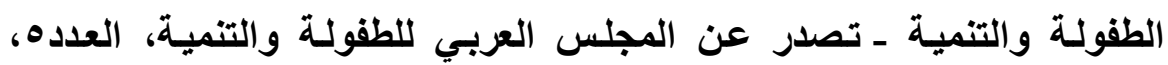

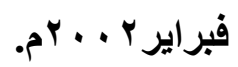

rهـ وسيم حسام الدين الأحمد: الحمايـة القانونيـة لحقوق المعاقين ذوي الاحتياجـات

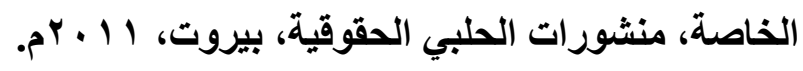

\section{ثانيا: المراجع الأجنبية:}

53- Kirk, S., \& Chalfant , J. (1984): Developmental and academic learning Disabilities . Denver : Liove Publishing.

54- Karin, Hess and Orthmann, Christine, Criminal Investigation, ninth edition, Canada, 2009. P.9.

55- Kirk, S., \& Chalfant , J. (1984): Developmental and academic learning Disabilities . Denver : Liove Publishing.

56- Osterburg, James and Ward, Richard, Criminal Investigation: A method for Reconstructing the Past, Sixth edition, USA, 2010. P31. 